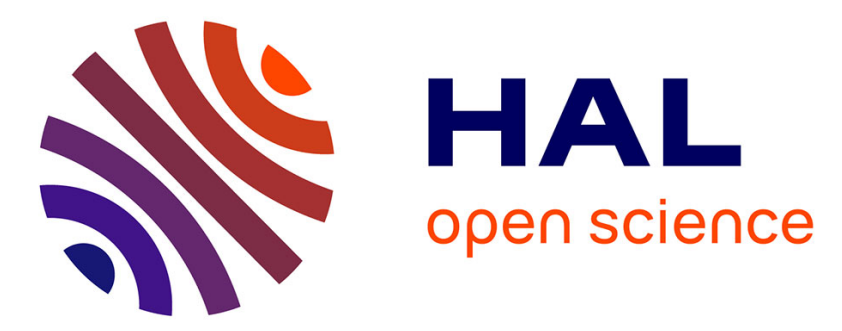

\title{
Analysis of the seismic activity associated with the 2010 eruption of Merapi volcano, Java
}

Agus Budi-Santoso, Philippe Lesage, S. Dwiyono, Sri Sumarti, S. Subandriyo, Surono Surono, Philippe Jousset, Jean-Philippe Métaxian

\section{- To cite this version:}

Agus Budi-Santoso, Philippe Lesage, S. Dwiyono, Sri Sumarti, S. Subandriyo, et al.. Analysis of the seismic activity associated with the 2010 eruption of Merapi volcano, Java. Journal of Volcanology and Geothermal Research, 2013, 261, pp.153-170. 10.1016/j.jvolgeores.2013.03.024 . hal-01021907

\section{HAL Id: hal-01021907 \\ https://hal.univ-grenoble-alpes.fr/hal-01021907}

Submitted on 15 Jul 2014

HAL is a multi-disciplinary open access archive for the deposit and dissemination of scientific research documents, whether they are published or not. The documents may come from teaching and research institutions in France or abroad, or from public or private research centers.
L'archive ouverte pluridisciplinaire HAL, est destinée au dépôt et à la diffusion de documents scientifiques de niveau recherche, publiés ou non, émanant des établissements d'enseignement et de recherche français ou étrangers, des laboratoires publics ou privés. 


\section{Analysis of the Seismic Activity Associated with the 2010

Agus Budi-Santoso ${ }^{1,2}$, Philippe Lesage ${ }^{2}$, Sapari Dwiyono ${ }^{1}$, Sri Sumarti ${ }^{1}$, Subandriyo ${ }^{1}$,

Surono $^{1}$, Philippe Jousset ${ }^{4,5}$, Jean-Philippe Metaxian ${ }^{2}$.

1'Badan Geologi, Jalan Diponegoro No. 57, 40122 Bandung, Indonesia (agusbudisantoso@yahoo.com), (s4par1@yahoo.co.id), (merapi_bpptk@yahoo.com), (jsubandriyo@gmail.com), (surono@vsi.esdm.go.id).+62 227272606

${ }^{2}$ ISTerre, CNRS, Université de Savoie, IRD 21973376 Le Bourget du Lac cedex, France. (lesage@univ-savoie.fr), (jean-philippe.metaxian@ird.fr).

${ }^{4}$ BRGM, RIS, 3 Avenue Claude Guillemin, BP36009, 45060 Orléans Cedex 2, France

${ }^{5}$ Now at Helmholtz Center GFZ, Telegrafenberg, 14473 Potsdam, Germany (pjousset@ggfz-potsdam.de) +49 302881299

Keywords

Merapi Volcano, Volcano Seismology, Eruption Forecasting, Pre-eruptive Seismicity, RSAM, Material Failure Forecast Method, Source Location.

\section{Abstract}

The 2010 large explosive eruption of Merapi is the first episode of this type that has been instrumentally observed on this volcano. The main features of the seismic activity during the pre-eruptive period and the crisis are presented in this paper. The first seismic precursors were a series of four shallow swarms 12 to 4 months before the eruption. They are interpreted as resulting from perturbations of the hydrothermal system by increasing heat flow. The precursory seismic activity strictly speaking started about 6 weeks before the explosion of October $26^{\text {th }}$. During this period, the rate of seismicity increased almost constantly yielding a cumulative seismic energy release for volcano-tectonic (VT) and multiphase events (MP) of $7.510^{10} \mathrm{~J}$. This value is 3 times the maximum energy release before former effusive eruptions of Merapi. The high level reached and the accelerated behaviour of both the deformations of the summit and the seismic activity are distinct features of the 2010 eruption with respect to previous events.

The hypocenters of VT events are split into two clusters with depths (below the summit) of [2.5-5] km and less than $1.5 \mathrm{~km}$, respectively. The aseismic zone at [1.5-2.5] km depth is a robust feature that was already detected in previous studies. This could correspond to a poorly consolidated layer which is part of the 'Ancient Merapi' structure. Most of deep VT events occurred before October $17^{\text {th }}$. After that, shallow activity strongly increased. This migration of the seismic sources is consistent with the final stage of a rapid magma ascent before the eruption. The deep seismic activity is interpreted as associated with the failure and enlargement of a narrow conduit by a large amount of rapidly ascending magma, while the shallow seismicity could be related to the rupture of the summit plug. 
Hindsight forecastings of the occurrence time of the eruption are performed by applying the Materials Failure Forecast Method (FFM). They use cumulative RSAM calculated either on the raw records or on signals classified according to their dominant frequency. Stable estimations are obtained during the last 6 days with fluctuations as small as \pm 4 hours around the time of the first explosion. This approach could thus be useful to support decision making in the case of future explosive episodes at Merapi assuming that similar precursory processes will occur.

\section{Introduction}

Merapi is located on Java Island, at about $30 \mathrm{~km}$ north of the city of Yogyakarta. It is considered to be one of the most dangerous volcanoes of Indonesia because of its densely populated surroundings and its high level of eruptive activity. The recent history of Merapi (Voight et al., 2000) is characterized by two eruptive styles: 1) effusive growth of viscous lava domes, with typical recurrence of 4 to 6 years, that gravitationally collapse producing pyroclastic flows known as « Merapi-type nuées ardentes »; 2) more exceptional explosive eruptions of relatively large size, associated with column collapse and pyroclastic flows reaching large distances. The October - November 2010 eruption is the first explosive type event of Merapi (VEI 4) that has been recorded by a multiparametric monitoring network and that was not preceded by emergence of lava dome. Previous instrumentally observed eruptions, in 1984, 1986, 1992, 1994, 1997, 1998, 2001, and 2006 (VEI = 1 - 3) were common lava extrusions followed by dome collapses. This situation offers a unique opportunity to compare the seismic activity associated with the two types of eruption and to look for precursory evidences of a transition between effusive and explosive styles.

As for most volcanoes in the world, the seismic activity of Merapi is characterized by a large variety of events that correspond to different locations and physical processes of the sources. Since 1984, the classification of events at Merapi includes the following types: deep (VTA) and shallow (VTB) volcano-tectonic, multiphase (MP), low frequency (LF), very long period (VLP) events, tremor and rock fall (Ratdomopurbo and Poupinet, 2000). Hypocenter distributions of VT events display an aseismic zone at 1.5-2.5 km depth (Ratdomopurbo and Poupinet, 2000; Wassermann and Ohrnberger, 2001; Hidayati et al., 2008) that has been interpreted as a ductile high-temperature zone.

Eruptions at Merapi are generally preceded by VT and MP seismicity on varying time scales from weeks to months (Ratdomopurbo and Poupinet, 2000; Voight et al., 2000; Suharna et al., 2007). However, some eruptions were not preceded by seismicity increase such as in 1986 and 1994. These later events are interpreted to be gravitational collapses of the dome. In 1991, about $25 \%$ of the shallow VT events belonged to seismic multiplets. These families of events with similar waveforms correspond either to sources very close to each other with identical focal mechanisms or to non-destructive and repetitive sources. Ratdomopurbo and Poupinet (1995) analyzed multiplets during 1992 by using a cross-spectral method on the coda waves. They detected an increase of the seismic velocity of $1.2 \%$ inside the volcano that may be related to the pressurization of the magma feeding system. Using records of a repeatable controlled source, Wegler et al. (2006) also observed an increase of the shear velocity before the 1998 eruption.

The velocity structure of Merapi is still poorly known. Active experiments using air gun shots in water basins have been carried out to investigate this structure (Lühr et al., 1998; Wegler et 
al., 1999). Because the direct P- and S-waves generated by superficial sources were rapidly attenuated due to strong scattering by the heterogeneous medium, no velocity model could be obtained by this approach. However, the spindle-like shape of the seismogram envelops could be explained by a diffusion model (Wegler and Lühr, 2001). Thus hypocenter determinations generally use a homogeneous model with P-wave velocity of $3 \mathrm{kms}^{-1}$ (Ratdomopurbo, 1995; Hidayati et al., 2008) or $2.8 \mathrm{kms}^{-1}$ (Wassermann and Ohrnberger, 2001). At a larger scale, a tomographic study (Koulakov et al. 2007, 2009; Wagner et al. 2007) revealed an exceptionally strong velocity anomaly in the crust between Merapi and Lawu (eastern of Merapi) volcanic groups, interpreted as a zone with high content of fluids and melts feeding the active volcanoes in the area.

Focal mechanisms of VT events recorded in 2000-2001 have been estimated by Hidayati et al. (2008) using both polarity and amplitude of P-wave first motions. For VTA and most deep VTB events, they are of normal-fault types while VTB located close to the surface are of both reverse and normal fault types. Hidayat et al. (2000; 2002) studied very-long period (VLP) events that occurred in 1998. These pulses with periods of 6-7 $\mathrm{s}$ and displaying similar waveforms from event to event are coeval with MP or LF earthquakes. Hidayat et al. (2002) carried out moment tensor inversion of the waveforms and proposed a source model consistent with a dipping crack located at about $100 \mathrm{~m}$ under the dome. They suggested a source process involving the sudden release of pressurized gas through the crack over a time span of about $6 \mathrm{~s}$. No VLP events were observed during the active periods of 2001 and 2006, while a significant number of VLP events were observed in 2010 prior to and during the eruption (Jousset et al., this issue).

In this paper, we present some aspects of the seismic activity of Merapi in the year preceding and during the 2010 eruption. We give a description of the types of seismic events observed and a detailed chronology of the seismicity during this period. The spatial and temporal distribution of the VT earthquake hypocenters provides important information on the preeruptive processes in the structure. We apply the Material Failure Forecast method (Voight, 1988) to the RSAM values and test the potential of this approach to forecast the time of the eruption onset. The comparisons between the features of the 2010 seismicity and those of preceding eruptions give some clues to distinguish explosive from effusive impending eruption.

\section{Seismic network}

The monitoring system of Merapi, operated by BPPTK (Balai Penyelidikan dan Pengembangan Teknologi Kegunungapian) - Volcano Observatory of Yogyakarta which belongs to CVGHM (Centre of Volcanology and Geological Hazard Mitigation), is mainly based on seismic, deformation and geochemical measurements. The permanent seismic network consists of four short-period (SP) stations equipped with L4C and L22 seismometers. Signals are transmitted to Yogyakarta by radio with VHF modulation and are digitized by a Güralp DM16S acquisition system at a rate of 100 samples per second with 16 bits accuracy. SP stations have been used as reference stations in routine analysis, such as event classification and counting, source location, and seismic energy calculations. In addition up to six broadband (BB) stations using Güralp CMG-40TD seismometers with period $60 \mathrm{~s}$ and TCP/IP protocol for data transmission have been installed on July 2009 and February 2010. Both types of stations use GPS clocks for synchronization and Güralp Compressed Format 
(GCF) for data file storage. Fig. 1 shows the configuration of the monitoring network; seismic stations are located on and around the volcano at distances to the crater ranging from 0 to 6 $\mathrm{km}$.

Some breakdowns in stations reduced the amount of available records during the pre-eruptive period. Fig. 2 summarizes the operation time intervals. Furthermore, the GPS clock of some broadband stations failed during several time intervals. In order to use arrival times from these stations for source location, a procedure of clock re-synchronization, based on seismic noise correlation (Stehly et al., 2007; Sens-Schönfelder, 2008), was applied. The cross-correlation function $(\mathrm{CCF})$ of the noise recorded in two stations is directly related to the Green function between the two sites (e.g. Campillo, 2006). When the clock of one of the stations is drifted, the CCF is delayed by the same lag with respect to that obtained when both clocks are synchronized. Thus, by locking for the maximum of the correlation function between the shifted and the reference CCF, it is possible to estimate the delay and to synchronize the stations. An estimated precision of $\sim 0.05 \mathrm{~s}$ is obtained with this approach which uses low-pass $(<4 \mathrm{~Hz}$ ) filtered signals (Fig. 3).

\section{Main features of the seismic events}

150 Since the installation of a telemetered network in 1982, the same classification of seismic signals has been used at Merapi for sake of consistency (Ratdomopurbo, 1995; Ratdomopurbo and Poupinet, 2000). The main types of signal are volcanotectonic (VT), multiphase (MP), low-frequency (LF), rockfall (RF), and tremor. VT events are characterized by clear onsets and high frequency content (up to $25 \mathrm{~Hz}$ ). They are associated with brittle failure in the rock and have generally simple double-couple mechanism (McNutt, 1996). VT events are similar to common tectonic earthquakes. The main differences are that the former are related to volcanic activity and they frequently occur in swarms (McNutt, 2000).

VT's at Merapi are sub-divided into deep (VTA) and shallow (VTB) events. VTA (Fig. 4a) are characterized by hypocenters at depth larger than $2 \mathrm{~km}$ below the summit, and clear P- and S-wave arrivals. VTB events have depths smaller than $2 \mathrm{~km}$ and more emergent onsets at distant stations (Fig. 4b). For some events, S-waves are undistinguishable. VTA and VTB events can be recognized by differences amplitude ratios for the first arrivals between summit (PUS) and flank (DEL) stations. Their differences in waveform and amplitude are probably related to a larger level of scattering and attenuation for paths in the shallow parts of the structure for VTB than for deeper paths for VTA (Wegler and Lühr, 2001).

Multiphase earthquakes are characterized by emergent onsets, maximum frequency of 4 to 8 $\mathrm{Hz}$, and shallow depth (Fig. 4c). This type of signal is similar to hybrid events in other classification schemes (McNutt, 1996). They are related to magma flow in the upper conduit and dome growth (Ratdomopurbo and Poupinet, 2000). Their rate of occurrence is sometimes correlated with summit deformations (Beauducel et al., 2000). Low-frequency earthquakes (LF), also called long-period (LP) events, have generally emergent onset, lack of S-wave arrival, and dominant peak frequency in the range [1-3] Hz (Fig. 4d). They are thought to be generated by resonance of fluid-filled cavities in the structure produced by pressure perturbations (Chouet, 1996). However, due to the strong attenuation of the high-frequency waves, some events identified as LF at distant stations may be actually MP events (Hidayat et $a l ., 2000$ ). Very-Long-Period (VLP) events occurred at Merapi in 1998 (Hidayat et al, 2002) and 2010 (Jousset et al., this issue) but were not observed in 2001 and 2006. This type of 
signal corresponds generally to the low frequency component of a MP or VT event and it is interpreted as mass transfer of fluid inside the structure (Ohminato et al., 1998; Legrand et al. 2000; Chouet et al. 2005; Waite et al., 2008, Jolly et al., 2012).

181

182

183

184

185

186

187

188

189

190

Tremor consists of long-lasting vibrations that are also associated with resonance effects in cavities (Chouet B., 1988; Konstantinou and Schlindwein, 2002), fluid flow (Rust et al. 2008), or degassing (Lesage et al., 2006). At Merapi they are relatively sparse, of low amplitude, and their spectra contain a few regularly spaced peaks, with fundamental frequency of [2-5] Hz (Fig. 5). They occurred more frequently in 2010 than before previous eruptions. Rockfalls (RF) are characterized by progressively increasing amplitude at the onset, long duration and high frequency content (5 to $20 \mathrm{~Hz}$ ). Pyroclastic flows (PF; Fig. 6), usually generated by dome collapse, produce RF-type signals with fairly long duration (up to tens of minutes) and large enough amplitudes to be recorded at the farthest stations.

\section{Chronological description of the pre- and co-eruptive seismicity}

This section summarizes the history of the seismic activity during the year preceding the eruption, with focus on the last few weeks and during the crisis. It mainly relies on routine manual counting and classification of events based on waveform shape. Daily statistics are thus made in local time (GMT+7). Seismic energy given below is calculated using the Gutenberg-Richter equation:

$$
\log E=11.8+1.5 M
$$

where $M$ is the magnitude (Gutenberg and Richter, 1956) and $E$ is in ergs. Magnitude of VT is calculated using local magnitude definition of Richter $(1935,1958)$. To minimize the influence of distance on the determination of magnitude of VTA and VTB, amplitudes measured at station DEL (2.6 km from summit) are used instead of that at the closest station PUS $(0.5 \mathrm{~km})$ since DEL is at about the same distance to the clusters of VTA and VTB. On the other hand, since the MP events always occurs at shallow depth and have low amplitude at station DEL, PUS is used to calculate the magnitude (Ratdomopurbo, 1995). Adequate amplitude corrections are applied to each station in order to get consistent magnitude determinations. During inter-eruptive periods, the level of seismic activity is usually very low. For example, following the 2006 eruption, an average of $5 \mathrm{MP}$ and less than one VT per day were registered. The total seismic energy (VT and MP) released per day was less than $0.410^{8}$ $\mathrm{J}$ on average. The first evidence of unrest was four short duration (3 to 4 hours) VT swarms that occurred on October $31^{\text {st }}$ (Fig. 7), December $6^{\text {th }}, 2009$, February $1^{\text {st }}$, and June $10^{\text {th }} 2010$. These swarms include a small number of detected events $(14,13,6$, and 30 , respectively) with maximum local magnitude of 2.5 and shallow depth $(<1 \mathrm{~km})$. This kind of activity is considered as an early precursor, as all the previous eruptions since al least 1992 were preceded by a series of seismic swarms.

In early September 2010, the level of seismicity began to increase, with about $10 \mathrm{MP}$ and 3 VT events per day and seismic energy released of $0.610^{8} \mathrm{~J}$ per day. On the $12^{\text {th }}$ at $8: 23$ local time, a VT earthquake with local magnitude $\mathrm{M}=2.5$ and depth of $3 \mathrm{~km}$ was felt in the three northernmost observation posts (Fig. 1). The earthquake was followed by a large rockfall at 10:21. A similar VT event occurred on September $13^{\text {th }}$ with magnitude of 2.4 and the same depth. As of September $19^{\text {th }}$, the rate of occurrence reached $38 \mathrm{MP}, 5$ VTA, and 6 VTB per 
day, with a total energy of $610^{8} \mathrm{~J}$ and a maximum magnitude of 2.6 (Fig. 8). This increasing seismicity coincided with accelerating inflation of the summit, as revealed by repeated distance measurements (Surono et al., 2012). On the basis of these observations, the alert level was raised to II on September 20 ${ }^{\text {th }}, 2010$ (Surono et al., 2012).

Harmonic tremors with weak amplitudes and durations of up to 70 minutes were detected from September $30^{\text {th }}$ to October $4^{\text {th }}$ at stations closest to the crater (Fig. 5). Spectrograms contain up to three regularly spaced peaks and display a phenomenon of frequency gliding which corresponds to progressive decrease of the fundamental frequency, from about 5 to 3 $\mathrm{Hz}$, and of the overtones frequency accordingly. This phenomenon forms cycles of 17 minutes duration, approximately. During the intrusive phase, 1-26 October, more than 200 VLP events were recorded, mostly at the summit stations and up to $\sim 3 \mathrm{~km}$ from the crater. They are characterized by frequency content in the range $[0.01-0.2] \mathrm{Hz}$ and they are coeval to VT, MP, or LF events (Jousset et al. this issue).

The seismic activity continued to increase in October together with deformation rate, gas emission, and changes in gas composition (Aisyah N. et al., 2010). The daily number of seismic events reached $56 \mathrm{VT}$ on the $17^{\text {th }}, 579 \mathrm{MP}$ and a total energy of $5110^{8} \mathrm{~J}$ on the $20^{\text {th }}$. An increasing number of rockfall also occurred with up to 85 events on the $20^{\text {th }}$ (Fig. 8). The alert level was raised to III on October $21^{\text {st }}$. On October $23^{\text {rd }}-24^{\text {th }}$, a total of 27 LF events occurred with dominant frequency in the range [1.5 - 2.5] Hz. Some of them produced amplitude saturation at short period stations. The largest ones were recorded at all the stations and could be located at a few hundreds of meters beneath the summit. The level of seismicity dramatically raised on October $24^{\text {th }}$ to $26^{\text {th }}$. On the $24^{\text {th }}$, the number of VT, MP, RF and the seismic energy were $80,588,194$, and $5910^{8} \mathrm{~J}$, respectively. On the $25^{\text {th }}$, the corresponding values were 222, 624, 454, and $13210^{8} \mathrm{~J}$. The alert was raised to level IV (evacuation) on October $25^{\text {th }}$ at 18:00 local time, 23 hours before the onset of the eruption. By the occurrence of the first eruption on October $26^{\text {th }}, 2010$ at 17:02 local time (10:02 UTC), 232 VT, 397 MP, $269 \mathrm{RF}$ and $4 \mathrm{LF}$ were counted with an energy of $19710^{8} \mathrm{~J}$.

The first phase of the eruption was phreato-magmatic explosive and produced a pyroclastic flow that reached up to $5 \mathrm{~km}$ to the South (Surono et al., 2012). The duration of the corresponding seismic signal was $330 \mathrm{~s}$. On October $27^{\text {th }}$, the seismicity decreased to 7 VT, $34 \mathrm{MP}, 1 \mathrm{LF}$, and $109 \mathrm{RF}$. During the two following days, the daily number of events rose again to $34 \mathrm{VT}, 129 \mathrm{MP}, 222 \mathrm{RF}, 7 \mathrm{PF}$, and to $67 \mathrm{VT}, 223 \mathrm{MP}, 354 \mathrm{RF}, 32$ small PF, respectively. The eruptive activity decreased afterward and only $4 \mathrm{PF}$ were observed on October $31^{\text {st }}$. Meanwhile a burst of 22 LF events and a weak 13 minutes long episode of tremor occurred this day.

High frequency tremor appeared on November $3^{\text {rd }}$ in relation with more and more frequent pyroclastic flows. At 11:00 local time, this tremor became continuous. At 16:05, authorities decided to enlarge the restricted zone to a radius of $15 \mathrm{~km}$ from the summit. At 18:46 a pyroclastic flow reached a distance of $9 \mathrm{~km}$ destroying seismic station KLA. On November $4^{\text {th }}$ and $5^{\text {th }}$, the SP seismograms were saturated and individual events were undistinguishable. However, by using low-pass filter $(\mathrm{f}<0.1 \mathrm{~Hz}$ ), it was possible to detect that the largest eruption took place on November $5^{\text {th }}$ at 00:01 local time (Nov. $4^{\text {th }}$ at 17:01 UTC - Fig. 6). This eruption lasted about 27 minutes, produced $15 \mathrm{~km}$ long pyroclastic flows, and destroyed stations DEL and PUS and broadband stations at the summit of the volcano. The same day at 01:00 local time, the radius of the restricted zone was set at $20 \mathrm{~km}$. 
In complement to seismic features such as daily number of earthquakes and source location, the cumulative energy of VT and MP events calculated over the preceding year has been used at BPPTK for estimating the current state of activity (Fig. 9). For eruptions before 2010, this energy ranged from $10^{10} \mathrm{~J}(10 \mathrm{GJ})$ in 1992 to $2.410^{10} \mathrm{~J}$ in 1997 and 2006 . Thus, in practice, special attention is paid to the monitoring observations when this energy reaches $10^{10} \mathrm{~J}$. On October $16^{\text {th }}$, the cumulative energy was $2.410^{10} \mathrm{~J}$ and an eruption or a dome extrusion was expected. However, the energy rate increased more rapidly instead with a maximum value of $0.6210^{10} \mathrm{~J}$ per day on October $25^{\text {th }}$. Together with the accelerating huge local deformations (displacement of up to 3 meters), the very high value reached by the energy was one of the key elements that pointed a much larger eruption than usual, yielding timely decision of evacuation. It is interesting to note that the cumulative energy for the 2010 eruption is lower than all the others between days 270 and 325 (95 to 40 days before the eruption onset). This indicates that, while seismic energy is progressively released during a long period before effusive eruptions, in the case of an explosive crisis, most of the energy is produced in the last few days or weeks.

\section{Source location}

From the data base of seismic events of Merapi, beginning in October 2009, 679 events, recorded on 4 to 9 seismic stations could be located. In the present work, the Hypoellipse program (Lahr, 1999) was used with a homogeneous half space velocity model assuming $V_{p}=$ $3 \mathrm{~km} \mathrm{~s}^{-1}$ and $V_{p} / V_{S}=1.86$ (Ratdomopurbo and Poupinet, 2000). In order to estimate realistic uncertainties on hypocenter positions, an approach by Monte-Carlo simulation was applied. The observed arrival times were modified by random perturbations with Gaussian distribution and standard deviation of $0.1 \mathrm{~s}$, and new hypocenter positions were obtained. This procedure was repeated 1000 times for each event. Outliers were removed by using the Thomson Tau method (Thomson, 1985). These outliers represent a small proportion of the whole set of solutions. The remaining solutions were used to calculate confidence ellipses for each event by carrying out principal component analysis (Jackson, 1988) on the covariance matrix of positions (Got et al., 2011).

Figure 10 displays the results on source location. The histogram of the uncertainties on depth (Fig. 10e) shows that most of them are smaller than $0.5 \mathrm{~km}$, with a maximum number close to $0.3 \mathrm{~km} .19$ events with uncertainty on depth larger than $1 \mathrm{~km}$ were removed before plotting the location map and cross-sections. Hypocenters are distributed at depth less than $5 \mathrm{~km}$ below the crater, in a cylinder with elliptical section of $2 \mathrm{~km} \times 1 \mathrm{~km}$ approximately and longest axis in the NE-SW direction (Fig. 10a-c). The distribution in depth is split into two separated clusters. The deepest one (about 116 events) lies between 2.5 and $5 \mathrm{~km}$ below the summit. It contains VTA type events following the classification used at Merapi (see section 3 ). The shallowest cluster is constituted by VTB events with maximum depth of $1.5 \mathrm{~km}$. Consequently, it appears that an aseismic zone does exist at depth of 1.5 to $2.5 \mathrm{~km}$ below the crater. This feature is also shown both by the histogram of the hypocenter depths and by the probability density function of the source depths which display clear minima at $1.5-2.5 \mathrm{~km}$ depth (Fig. 10d). In order to verify whether this gap is due to an artefact of the hypocenter determination, source depths are plotted as a function of differences of P-waves arrival times $\left(t_{D E L}-t_{P U S}\right)$ between stations DEL (located $1.5 \mathrm{~km}$ below the summit) and PUS which is close to and $200 \mathrm{~m}$ below the summit (Fig. 10f). Again, two clusters can be observed in this representation, separated mainly along the $\left(t_{D E L}-t_{P U S}\right)$ axis. Values of $\left(t_{D E L}-t_{P U S}\right)$ in the range $[\sim 0-0.25] \mathrm{s}$ are associated with deep VTA events while time differences of 0.35 to $1 \mathrm{~s}$ 
correspond to shallow VTB earthquakes. The relative lack of values between 0.25 and $0.35 \mathrm{~s}$ is a robust observation and is consistent with the existence of an aseismic zone at $1.5-2.5 \mathrm{~km}$ depth.

The four seismic swarms that occurred from October 2009 to June 2010 were located at less than $1 \mathrm{~km}$ below the summit. They include thus mostly VTB events. In Fig 11, hypocenter depths are plotted as a function of time. The numbers of VTA and VTB per day are also presented. It appears clearly that the VTA events occurred during the first part of the preeruptive period until around October $17^{\text {th }}$. After that, while VTA activity was vanishing, a sharp increase of the number of VTB events was observed until the eruption. Therefore, a migration of the seismic activity from deep to shallow part of the edifice seems to have occurred about 10 days before the eruption.

\section{RSAM and hindsight forecasting}

Real Time Seismic Amplitude Measurement (RSAM) is a robust tool for monitoring volcanic activity because it provides a simple indicator of the level of seismic energy released (Endo and Murray, 1991). At Merapi, real-time monitoring by RSAM was carried out during the critical period of the eruptive crisis of 2010 . For this, a module made by BPTTK calculated every 5 minutes the RSAM value from the discriminator output of station KLA (Fig. 1). It provided valuable information on the increasing seismic activity before the eruption and on the energy of eruptive events during the crisis which was of great help in managing the situation (Fig. 8f).

In order to carry out more detailed analysis, we recalculated RSAM from digital raw data of station PUS as

$$
R S A M=\frac{\sum_{i=1}^{n}\left|A_{i}-\bar{A}\right|}{n}
$$

where $A_{i}$ is the signal amplitude, $\bar{A}$ the mean amplitude in the calculation window, and $n$ the number of samples of the window. An initial window length of two minutes was used and, for long-term analysis, a mean value every two hours was calculated. Because the whole hardware of station PUS was replaced on April 2010 by new equipment with different sensitivity, an amplitude correction was applied for sake of consistency between data recorded before and after the change. Furthermore, because the tectonic earthquakes are not related to volcanic activity, they were removed from RSAM values thanks to the daily seismicity counting catalogue and low pass filtering to identify their coda.

RSAM is calculated on the continuous record which includes signals of all types. In order to get some more details and as an attempt to separate the contribution of different types of source, the following procedure was applied. For each 1-mn long window, a spectrum is calculated and the frequency of its maximum is determined. Then the segment of record is classified according to this peak frequency among the following ranges: [0.01 - 1] Hz, [1-3] $\mathrm{Hz},[3-5] \mathrm{Hz},[5-10] \mathrm{Hz}$ and [1-15] Hz. Because a segment generally contains no more than one event, this classification of signals roughly corresponds to the different types of event defined in section 3. Range [1-15] Hz includes all the events but the noise is reduced. After 
that, a cumulative value of RSAM is calculated for each frequency range. This procedure gives different results than the Seismic Spectral Amplitude Measurement (SSAM, Stephens et al., 1994) which is the mean level of signal filtered in different frequency ranges. For example, in the range [1-3] Hz which contains mostly LF events, it helps separating the contribution of these low amplitude events that occurred a few days before the onset of the eruption (Fig. 12).

Starting October 2009, the average value of RSAM is almost constant in spite of some small bursts of energy related to the seismic swarms. A slight increase of RSAM is first observed on September $12^{\text {th }} 2010$, followed by an accelerating release of energy until October $6^{\text {th }}$. This day, a marked decrease of RSAM was observed. This behaviour appears clearly on the smoother curve of cumulative values which displays a discontinuity of its slope on October $6^{\text {th }}$ (Fig. 13). After that, RSAM presents again an accelerating behaviour till the first eruption on October $26^{\text {th }}$. Other accelerating phases are observed before the eruptions of October $29^{\text {th }}$ and November $3^{\text {rd }}$. The maximum values of RSAM provide also qualitative indications on the relative amplitude of the different stages of the eruptive sequence. The first eruption of October $26^{\text {th }}$ is associated with a maximum RSAM value of $3.710^{5}$ arbitrary unit (A.U). However, since the onset of eruption many seismic signals are saturated. Thus the RSAM associated with the eruption phases is under estimated. The following eruptions until November $2^{\text {nd }}$ produce smaller maxima. RSAM peaks at $5.710^{5} \mathrm{~A} . \mathrm{U}$ on November $3^{\text {rd }}$ and then reaches its highest values, $6.710^{5}$ A.U., on November $4^{\text {th }}$, when the station was destroyed. The RSAM in the bands [3-5] and [5-10] Hz displays similar behaviour before the onset of the eruption. After that, RSAM in the band [3-5 Hz] displays a relative decrease in comparison with the other frequency bands. As the former range contains mostly VT events, this observation suggests that the fraction of energy released by brittle fracture is lower after the eruption onset. This is consistent with a condition of open conduit.

Accelerated rates of seismicity have been observed over different time scales before many eruptions (see e.g. Tokarev, 1971; Voight, 1988; Cornelius and Voight, 1994; Kilburn and Voight, 1998; De la Cruz-Reyna and Reyes-Davila, 2001; Kilburn, 2003; Smith et al., 2007; Arambula et al., 2011; Traversa et al., 2011). This behaviour is at the basis of the Material Failure Forecast Method (FFM) that has been widely used for estimating the time of an eruption (Voight, 1988; Cornelius and Voight, 1994, 1995; De la Cruz-Reyna and ReyesDavila, 2001). First introduced for the study of landslides (e.g. Fukuzono and Terashima, 1985), the FFM assumes that a pre-eruptive stage is analogous to a damaging or creep process before the failure of the material. An observable $\Omega$ related to this process, such as displacement, strain, or level of seismic activity, is governed by an empirical power law between its rate of change $\dot{\Omega}$ and acceleration $\ddot{\Omega}$ :

$$
\ddot{\Omega}=A \dot{\Omega}^{\alpha}
$$

where $A$ and $\alpha$ are constants that can be estimated from the observations (Cornelius and Voight, 1995). $\alpha$ is found to lie between 1 and 2, generally closer to 2 (Voight, 1988). For $\alpha=$ 2, equation 3 can be solved by integration yielding:

$$
\Omega=\frac{-1}{A} \ln \left[\frac{A\left(t^{*}-t\right)+\left(\dot{\Omega}^{*}\right)^{-1}}{A\left(t^{*}-t_{0}\right)+\left(\dot{\Omega}^{*}\right)^{-1}}\right]+\Omega_{0}=B \ln (1+s t)+C
$$


(Cornelius and Voight, 1995), where $\Omega\left(t=t_{0}\right)=\Omega_{0}$ and $\dot{\Omega}\left(t=t^{*}\right)=\dot{\Omega}^{*}$. B and C are constants and $\mathrm{C}$ can be chosen null. $s=-1 / t_{f}$, with $t_{f}$ the predicted time of failure or eruption which corresponds to $\Omega$ infinite. The time of failure $t_{f}$ can be used as an estimation of the time of the eruption onset. However there can be a time delay between them (Voight, 1988; Bell et al., 2011a)

Exercises of hindsight prediction of the eruption time were carried out by fitting a function given by Eq. 4 to the observed cumulative values of RSAM. Note that RSAM is approximately proportional to the seismic moment-rate and energy-rate and thus can be used as $\dot{\Omega}$ (Cornelius and Voight, 1995). Thereby cumulative values of RSAM can be modelled by function $\Omega$ in eq. 4 . For each trial, constants $B, s$, and $t_{f}$ are estimated by least squares fitting. In this task, a crucial issue is the choice of the time window used to fit the model to the data. As described in section 4, a first clear increase of the seismicity was observed on September $12^{\text {th }}$. Then a sudden decrease of the slope of the cumulative RSAM occurred on October $6^{\text {th }}$ followed by another acceleration stage until October $26^{\text {th }}$. A first trial was made with a fitting window from September $13^{\text {th }}$ to October $5^{\text {th }}$ (Fig. 14). For this interval the adjustment is excellent (correlation coefficient of $99.9 \%$ ) and the predicted failure time is on October $26^{\text {th }}$ at 07:00, 3 hours before the eruption onset. However a clear departure between the theoretical and observed curves appears after October $6^{\text {th }}$. Another trial was thus made with a fitting window starting on October $7^{\text {th }}$ and ending on the $25^{\text {th }}$ (Fig. 14). The predicted time is October $26^{\text {th }}$ at 19:00 (time lag of 9 hours) and again, the correlation coefficient in this interval is very close to one. These first results confirm that the FFM model used is suitable to explain the observations in the two time periods. However large modifications probably occurred in the volcanic system around October $6^{\text {th }}$ and make it more difficult to apply the method. More general solutions of eq. 3 were also considered, with $\alpha \neq 2$. In this case, $\alpha$ is an unknown parameter which is estimated together with $t_{f}$. In almost all these trials, the resulting value of $\alpha$ is very close to 2 .

In order to test more in detail the robustness of the model as forecasting tool, a series of trials was carried out using different fitting time windows. In the following discussion, all dates are in October and $\mathrm{t}=20$ corresponds to October $20^{\text {th }}$ for example. The windows have starting time $t_{\text {start }}=7$ and their ending times $t_{\text {end }}$ varies up to 26 . The observations are either cumulative RSAM or cumulative RSAM calculated on signals classified by frequency range. The differences between the predicted time of failure $t_{f}$ and the time $t_{\text {erupt }}$ of the first eruption (October $26^{\text {th }}$ 10:02 UTC) are plotted as a function of $t_{\text {end }}$ in Fig 15.

For $t_{\text {end }}<13$, the predicted time $t_{f}$ is erratic and cannot be used. However, for $t_{\text {end }}>13, t_{f}$ $t_{\text {erupt }}$ and then converges toward $t_{\text {erupt }}$ for $t_{\text {end }}>20$ (Fig. 15a). Similar results are obtained with $t_{\text {start }}=6$ or 8 .

431 The use of RSAM calculated on signals classified following their dominant frequency yields similar results and seems to improve the precision of the prediction. For $t_{\text {end }}>20, t_{f}-t_{\text {erupt }}$ is positive and smaller than 0.5 and 0.7 days, for ranges [0.01-1] and [1-15] Hz, respectively (Fig. 15b\&e). For the band [5-10] Hz, $t_{f}-t_{\text {erupt }}$ is negative and tends to zero for increasing $\mathrm{t}_{\text {end }}$ (Fig. 15d). In the range [3-5] Hz, the estimated time of failure varies in the interval $t_{f}=t_{\text {erupt }} \pm 4$ hours during the last 6 days before the first eruption (Fig. 15c). 
Because the deformation displayed acceleration behaviour before the eruption, the same FFM approach can be applied. In this case, observations are the variation of the slope distance between Kaliurang observatory and a reflector located on the southern part of the summit (Fig. 1). Measurements were carried out by EDM (Electronics Distance Measurement) almost every day. The adjustment between these observations and function $\Omega$ given by eq. 4 is not as good as that obtained for RSAM (Fig. 16) Moreover, for the deformations, the estimated values of $t_{f}$ increase monotonically and tends toward the time of eruption onset for $t_{\text {end }}$ close to $t_{\text {erupt }}$ (Fig. 15f).

\section{Discussion}

The seismic activity of Merapi during the pre-eruptive period and the eruption of 2010 presents features commonly observed during previous eruptions and some characteristics that had never been recorded before, such as its high level of energy release. The types of event identified in 2010 are similar to those observed since seismic stations were installed on the volcano. Although empirically designed from waveform observations, the event classification reflects the diversity of physical processes and locations of seismic sources. The two types of volcano-tectonic event, VTA and VTB, correspond to two depth ranges for their hypocenters. They are easily distinguished by different amplitude patterns in the seismic network and by distinct differences of P-wave arrival times between stations, while it is difficult to recognize them with only one station. The most numerous events are multi-phase, as hundreds of MP signals were counted daily before and during the eruption (Fig. 6). They are interpreted as fragile ruptures that trigger resonance response of an adjacent magma-filled conduit or crack. They are mainly observed accompanying magma extrusions or in association with dome instabilities. However MP events can also occur during periods of quiescence. Their origins and source mechanisms are thus still not well-known and require further studies including precise hypocenter determinations.

Unlike many other volcanoes, low-frequency (LF or LP) events and tremor are relatively scarce on Merapi. Most of the mechanisms that have been proposed to explain these kinds of event involve fluids interacting with the surrounding medium (Chouet, 1996). In the case of Merapi, LF events mainly occured at shallow depths after the first phreatomagmatic explosions (Jousset et al., - this issue). They probably result from the interaction of the intrusive magma body with the hydrothermal system that lies beneath the summit (Müller and Haak, 2004). The few harmonic tremors detected during the pre-eruptive period are probably associated with the increasing gas emission. A possible mechanism for these vibrations is the periodic opening and closing of a valve in a crack that produce intermittent pulses of gas with frequency stabilized by the resonance of the fluid-filled cavity in the same manner as in a clarinet (Lesage et al., 2006). This process generates regularly spaced spectral peaks by the Dirac comb effect and is an efficient mechanism to radiate seismic waves (Rust et al., 2008). The frequency gliding displayed in spectrograms may result from variations of the wave velocity in the resonator due to varying content of two-phase fluid (such as gas bubbles in water or magma), or to changes in the cavity itself modifying its length or stiffness.

Hypocenter determination is a difficult task on volcanoes because of lack of clear phase arrivals, especially for MP, LF, and tremor events, sharp topography, limited knowledge of the velocity structure, and, eventually, a too small number of stations. These drawbacks produce sometimes bad precision in source location, especially in depth, yielding fuzzy patterns of hypocenter distribution that are difficult to interpret. It is thus necessary to obtain reliable estimations of uncertainties on source positions. While the errors calculated by the 
programs of hypocenter determination depend mainly on the consistency between the observed arrival times, the Monte-Carlo approach gives more robust estimations as it takes the geometry of seismic rays into account (Got et al., 2011). However, errors due to bad knowledge of the structure are not included in this procedure. Following the Monte-Carlo approach, the clouds of points obtained during a simulation provides an approximation of the probability density function of the source position. Its maximum can be taken as the hypocenter and its spread and shape reflect the precision of this determination. Nevertheless, precise hypocenter determination for a larger proportion of earthquakes will require a combination of a larger number of stations, with broader band and three-components seismometers, seismic arrays, and better velocity models. Automatic data processing and source location will be also very useful during the next crises.

The aseismic zone that appears between 1.5 and $2.5 \mathrm{~km}$ depth is a robust feature of the seismicity of Merapi. The present results confirm the findings of Ratdomopurbo and Poupinet (2000), Wassermann and Ohrnberger (2001), and Hidayati et al. (2008), that were obtained for seismic events recorded in 1991, 1998, and in 2000-2001, respectively, and show that it is a permanent structure over at least 20 years. Ratdomopurbo and Poupinet (2000) postulated that it could correspond to the presence of a more ductile zone related to a small shallow magma reservoir. However, deformation measurements (Beauducel et al., 1999) and electromagnetic data (Commer et al., 2006) are not consistent with such a shallow storage zone. Alternatively, the aseismic zone could correspond to the part of the Ancient Merapi left by the Holocene sector collapses (Newhall et al., 2000). This layer is mainly composed of auto-brecciated lava flows, St. Vincent-type pyroclastic flows and lahar deposits (Berthommier et al., 1990). It is probably poorly consolidated and thus less seismogenic than the surrounding layers. Indeed, it lies between the older structure of Pre-Merapi period and the series of andesitic lava flows and pyroclastic flows of the Middle and Recent Periods (Camus et al., 2000).

The first seismic observation of unrest of the volcano was a series of swarms of shallow VT events in October 2009, December 2009, February and June 2010. Seismic swarms are generally triggered by variations of the effective stress in fractures (Saccorotti et al., 2001). In the case of Merapi, they could be related to the perturbation of the hydrothermal system due to the intrusion of a deep hot body or to heating by increasing gas flow through the structure. Some deeper earthquakes occurred also before and after the eruption in the close vicinity of Merapi. Establishing a clear relationship between these events and the eruption requires more detailed studies. The precursory seismic activity strictly speaking started at the beginning of September 2010, about a month and a half before the eruption onset. Most VTA events, with focal depths of 2.5 to $5 \mathrm{~km}$, occurred before October $17^{\text {th }}$. After this date, VTA became very scarce while shallow $(<1.5 \mathrm{~km})$ VTB activity strongly increased. Although the focus of seismic activity is not necessarily close to the head of a magmatic intrusion, the marked change in hypocentral positions is quite consistent with the final stage of a rapid ascent of magma shown by petrological data (Surono et al., 2012).

The cumulative seismic energy release through VT and MP earthquakes during the year preceding the eruption reached $7.510^{10} \mathrm{~J}$. For the previous eruptions of 1992 to 2006 , this energy never exceeded $2.510^{10} \mathrm{~J}$. This much higher level of energy is the most important seismic characteristics of the 2010 eruption and is clearly consistent with its highly explosive nature. Most of this energy was emitted in the last 6 weeks before the initial eruption of October $26^{\text {th }}$ with a striking accelerating rate. Together with deformation and gas emission measurements, this observation formed the basis of the identification of the impending large eruption and the timely decision of evacuation within a more extended region than usual 
(Surono et al., 2012). Seismic activity originates mainly from mass movements inside the structure, such as magma intrusion and gas release, which produces stress variations and ground deformations. There is thus a relationship between seismic energy release, deformation, and volume change (McGarr, 1976; Yokoyama, 1988). In 2010, the bulk volume of juvenile deposits was estimated at $0.03-0.06 \mathrm{~km}^{3}$ (Surono et al., 2012), while the corresponding value was $0.01 \mathrm{~km}^{3}$ in 2006 (Sri-Sayudi et al., 2007). The marked difference between seismic energy release in 2010 and during previous eruptions can be thus related with difference of magma volume. The high level of energy in 2010 is thus consistent with the rapid ascent of a large amount of volatile-rich magma (Surono et al., 2012). This much larger volume of magma through the relatively narrow 2006 conduit produced rock damaging, creep, connexion of pre-existing network of cracks, and failure (Voight, 1988; De la CruzReyna and Reyes-Davila, 2001; Kilburn, 2003), resulting in conduit enlargement and higher seismic activity. From this point of view, the system could be considered as almost closed before the 2010 crisis. The accelerating seismic activity is also related to the accelerating deformation of part of the summit and both phenomena can be considered as precursory signs of a large explosive eruption. This behaviour significantly differs from those observed before the previous effusive eruptions where no strongly accelerating energy release or deformation occurred during the pre-eruptive stage (Ratdomopurbo and Poupinet, 2000; Voight et al., 2000).

The seismic energy release before this eruption is of medium order of magnitude compared with those of other eruptions of andesitic or dacitic volcanoes. For example, it is much higher than the cumulative energy release before the 1990 Kelut eruption (5.6 $10^{8} \mathrm{~J}$; Lesage and Surono, 1995) and that of Redoubt in 1989-1990 (>10 J; Power et al., 1994). A similar order of magnitude was obtained at Bezymianny in 1955 (4 10 $\left.{ }^{11} \mathrm{~J}\right)$, Tokachi in $1962\left(510^{10} \mathrm{~J}\right)$, or El Chichon $\left(10^{11} \mathrm{~J}\right)$ in 1982 (Tokarev, 1985; Yokoyama, 1988). On the other hand, the energy release at Merapi is more than one order of magnitude smaller than at Shiveluch in 1964 (1.2 $10^{12} \mathrm{~J}$; Tokarev, 1985) and at Mt St Helens before its large eruption in $1982\left(\sim 810^{12} \mathrm{~J}\right.$; Yokoyama, 1988; Qamar et al., 1983). Note that in the latter two cases, the eruptions were associated to the emplacement of a cryptodome and to the gravitational collapse of the volcano flank. The corresponding mechanical behaviour of Shiveluch and Mt St Helens were thus quite different from that of Merapi.

The accelerated rate of seismic energy was clearly reflected in the RSAM values and offered an interesting opportunity to test the Material Failure Forecast method (Voight, 1988). The results obtained with this model on Merapi show its ability to forecast the eruption time several days before with good precision. The hindsight forecasting trials carried out in this study may help describing a scenario of what would have been obtained if this FFM approach were applied during the pre-eruptive period. Using a starting time on September $12^{\text {th }}$ for calculations, a first estimation of the eruption time would have been obtained before October $6^{\text {th }}$ with very good precision (difference between predicted and eruption times of 3 hours). After this date, because of a marked change in the RSAM tendency, the forecasted time would have shown strong variations for increasing ending time of the fitting window. In addition a larger and larger departure between observed and calculated curves would have appeared. Then it would have been necessary to modify the starting time of the fitting window to the $7^{\text {th }}$ of October. In the subsequent daily trials, the estimated eruption time progressively converges toward the previous estimation and, for ending time later than October $20^{\text {th }}$, it becomes quite stable with a departure from the eruption time smaller than 1.5 days. The use of RSAM calculated with signals classified according their dominant frequency completes and improves the results. For example, for dominant frequencies in the range [3-5] Hz, the forecasted time 
is quite stable and its difference with the time of occurrence of the first explosion is smaller 581 than 4 hours during the last 6 days of the pre-eruptive period.

582 These encouraging results are obtained with the assumption that exponent $\alpha$ in the basic 583 equation of FFM (eq. 3 ) is equal to 2. In previous studies, $\alpha$ was found to be close to this 584 value which yields mathematical simplifications in the solution of the equation (Voight, 1988; Cornelius and Voight, 1995). In the present case, the direct estimations of $\alpha$ which gave values close to 2 and the good fitting between the observations and the theoretical curves confirms the choice of the exponent.

588 The accelerated behaviour of some parameters used in volcano monitoring has been interpreted as resulting from damaging processes of solid materials before their failure (Voight, 1988; 1989; Cornelius and Voight, 1994). Kilburn (2003) associated the accelerating rate of seismicity with the growth and the progressive connection of arrays of pre-existing fractures while magma propagates to the surface. De la Cruz-Reyna and Reyes-Davila (2001) applied a Kelvin-Voigt viscoelastic model to describe the tertiary creep associated with degradation and weakening of the medium preceding the rupture. They fitted a logarithmic curve, similar to eq. 4 , to the cumulative value of the root mean square of the seismic signal recorded before eruptions of Colima volcano, Mexico, and gave correct predictions of their time of occurrence. In any of these interpretative models, the system must be closed before the unrest. Most of the features of the seismic activity preceding the 2010 eruption of Merapi volcano indicate that the magmatic conduit was indeed closed or almost closed in relation to the large volume of magma that was intruding. Therefore the physical conditions required by the models to produce good estimations of the time of eruption were probably fulfilled in this case. On the contrary, before preceding eruptions of Merapi, such as that of 2006, no marked accelerating behaviour was observed which is consistent with a much smaller volume of magma extruding through an open conduit. Thus, it appears that better forecasts could be obtained with FFM for large explosive crisis than for small effusive events. Note that, although FFM can provide useful indications on the onset time, it cannot forecast the size on the impending eruption.

608 One of the main difficulties in using the FFM approach in real-time would have come from 609 the sharp variation in the RSAM rate that occurred around October $6^{\text {th }}$. Similar variations were observed before two eruptions of Colima volcano (De la Cruz-Reyna and Reyes-Davila, 2001). In the case of Merapi, this change may be related with the upward migration of the focal depths. This stage may be interpreted as the intrusion of the magma in the aseismic ductile zone at $1.5-2.5 \mathrm{~km}$ depth followed by the progressive failure of the overlying plug that was the last barrier for the magma to reach the surface. The magma progression through layers of different mechanical strength may have produced variable load regimes on the material yielding fluctuations in the accelerated behaviour of RSAM.

617 When using the FFM or similar methods for operational forecasting, it is of paramount 618 importance to take into account the many possible sources of uncertainty on the estimation of 619 the eruption time (Bell et al., 2011b). Part of the uncertainty comes from the choice of the time window used to fit the theoretical curve. In this work, several starting times and many ending times of the window have been systematically tested in order to study the stability of the estimations and to obtain more confident results. On the other hand, the models are slightly improved when classified signals are used to calculate RSAM instead of the complete raw records. The best results are obtained for signals with dominant frequency in the range [35] Hz which contains mainly VT events. This is consistent with the interpretation of the FFM method as discussed above. The very short lag between the estimated times of failure and the 
eruption onset suggests that the first explosion occurred immediately after the rupture of the last plug in the conduit. The displacement of part of the summit, measured by EDM, displays also acceleration behaviour. However the use of these observations for eruption forecasting does not give stable and usable solutions. This sector of the crater wall was probably partly

\section{Conclusion}

After an exceptional eruption, it is of paramount importance to carry out a thorough analysis of all the observations produced by the monitoring network and which could not be processed in detail during the crisis. This paper presents some results obtained in this process for the seismic data. Many aspects of the Merapi seismicity in 2010 still remain to be studied and this work is in progress. However at this stage, important features have been already underlined. Beside some early seismic swarms observed 12 to 4 months before the 2010 crisis, the seismic activity of Merapi increased almost monotonically during the last 6 weeks. The number of LF events, VLP events and tremors recorded in this period were larger than for common eruptions. However the most relevant characteristics of the 2010 activity are 1) the high level of seismic energy release, about three times the maximum value obtained for the previous eruptions, and 2) the clear accelerated behaviour observed in the number of VT and MP events, in the release of energy, and in the RSAM values. This behaviour is consistent with the strong acceleration of the displacement of some benchmarks of the summit measured by EDM. These features can be considered as clear evidences that the impending eruption would be much larger than the frequent effusive events. Indeed, they contrast with those of previous eruptions which were not preceded by such marked accelerations.

The good fitting and hindsight forecasting obtained in applying the FFM to RSAM calculated in the pre-eruptive period result from the accelerated nature of this seismicity. This is consistent with evidences that the volcanic system was almost closed with respect to the rapid intrusion of a large volume of magma, in agreement with the high level of energy release and the explosive eruption on $26^{\text {th }}$ October. The trials of a posteriori prediction of the eruption time shows that good precision can be achieved if magma and hypocenter migrations and/or changes of load regime, which may modify the evolution of the observables, are identified and if the forecasting strategy is adapted to this situation. The abrupt modification that appeared in the RSAM rate around October $6^{\text {th }}$ is probably related with the upward shift of the most seismically active region from below to above the aseismic zone located between 1.5 and $2.5 \mathrm{~km}$ depth beneath the crater.

662 In the future, if an episode of unrest of the seismic activity of Merapi produces a large 663 cumulative energy release, with respect to that of the frequent effusive eruptions, with a clearly accelerated rate, and if other observables, such as deformation or gas emission, present similar behaviour, then a large explosion of the same type as that of 2010 should be considered as highly probable. In this case, on condition that their limitations are well understood, the FFM or similar methods would be of great help in supporting decision making for evacuation. 


\section{Acknowledgment}

We wish to acknowledge the efforts of BPPTK staff especially Ilham Nurdin, Febri Sadana, and Purwoto for their struggle to ensure the seismic stations work properly. We are grateful to VDAP USGS for the assistance and equipment of short period stations and to MIAVITA project for the equipments of broadband stations. The MIAVITA project was financed by the European Commission under the $7^{\text {th }}$ Framework Program for Research and Technological Development, Area "Environment", Activity 6.1 "Climate Change, Pollution and Risks". We'd like to thank the Ministry of Energy and Mineral Resources of Indonesia for the doctoral scholarship granted to Agus Budi-Santoso. This work was partially supported by the Coopération Franco-Indonésienne funded by the French Ministère des Affaires Etrangères, by the Universite de Savoie and the Institut de Recherche pour le Développement. The catalogs of seismicity of previous eruptions made by Suharna are greatly appreciated. Discussions and suggestions from Jean Luc Got and Jean-Claude Thouret are gratefully acknowledged. We thank Ulrich Wegler, John Pallister and an anonymous reviewer for their interesting and useful comments.

\section{References}

Aisyah, N., Sumarti, S., Sayudi, D. S., Budisantoso, A., Muzani, M., Dwiyono, S., Sunarto, Kurniadi, 2010. Aktivitas G. Merapi Periode September - Desember 2010 (Erupsi G. Merapi 26 Oktober - 7 November 2010). Bulletin Berkala Merapi, 07/03.

Arámbula-Mendoza, R., P. Lesage, C. Valdés-González, N.R. Varley, G. Reyes-Dávila, C. Navarro, 2011. Seismic activity that accompanied the effusive and explosive eruptions during the 2004-2005 period at Volcán de Colima, Mexico, J. Volcanol. Geotherm. Res., 205, 30-46, doi:10.1016/j.jvolgeores.2011.02.009.

Beauducel, F. and Cornet, F.-H., 1999. Collection and three-dimensional modeling of GPS and tilt data at Merapi volcano, Java. J. Geophys. Res, 104(B1), 725-736.

Beauducel, F., F.H. Cornet, E. Suhanto, T. Duquesnoy, and M. Kasser, 2000. Constraints on magma flux from displacements data at Merapi volcano, Java. J. Geophys. Res. 105, 8193-8204.

Bell A. F., Greenhough J., Heap M. J., Main I. G., 2011a. Challenges for forecasting based on accelerating rates of earthquakes at volcanoes and laboratory analogues, Geophys. J. Int., 185, 718-723.

Bell A. F., Naylor M., Heap M. J., Main I. G., 2011b. Forecasting volcanic eruptions and other material failure phenomena: An evaluation of the failure forecast method, Geophys. Res. Lett., 38, L15304, doi:10.1029/2011GL048155. 
Berthommier, P., Camus, G., Condomines, M., Vincent, P.-M.,1990. Le Merapi (Centre Java): Eléments de chronologie d'un strato-volcan andésitique. C. R. Acad. Sci. Paris 311 (II), 213-218.

Campillo, M., 2006. Phase and correlation in 'random' seismic fields and the reconstruction of the Green's function. Pure Appl. Geophys., 163, 475-502.

Chouet, B. ,1988. Resonance of a fluid driven crack: Radiation properties and implications for the source of long-period events and harmonic tremor, J. Geophys. Res., 93, 43754400 .

Chouet, B., 1996. Long-period volcano seismicity: its source and use in eruption forecasting. Nature, 380, 309-316.

Chouet, B., Dawson P.,\& Arciniega-Ceballos, A., 2005. Source mechanism of Vulcanian degassing at Popocatépetl Volcano, Mexico, determined from waveform inversions of very long period signals, J. Geophys. Res., 110, B07301, doi:10.1029/2004JB003524.

Camus, G., Gourgaud, A., Mossand-Berthommier, P.C., Vincent, P.M., 2000. Merapi (Central Java, Indonesia): an outline of the structural and magmatological evolution, with a special emphasis ti the major pyroclastic events, J. Volcanol. Geotherm. Res. 100:139163. Doi:10.1016/S0377-0273(00)00135-9

Commer, M., Helwig, S.L., Hördt, A., Scholl, C. and Tezkan, B., 2006. New results on the resistivity structure of Merapi Volcano (Indonesia), derived from three-dimensional restricted inversion of long-offset transient electromagnetic data. Geophys. J. Int., 167, 1172-1187.

Cornelius, R.R., Voight, B., 1994. Seismological aspects of the 1989-1990 eruption at Redoubt volcano, Alaska: the materials failure forecast method (FFM) with RSAM and SSAM seismic data. J. Volcanol. Geotherm. Res. 62, 469-498.

Cornelius RR, Voight B, 1995. Graphical and PC-software analysis of volcano eruption precursors according to the Materials Failure Forecast Method (FFM). J Volcanol Geotherm Res 64, 295-320

De la Cruz-Reyna S., and G. A. Reyes-Dávila, 2001. A model to describe precursory material-failure phenomena: applications to short-term forecasting at Colima volcano, Mexico Bull Volcanol. 63,297-308

Endo, E. T., and T. Murray, 1991. Real-time Seismic Amplitude Measurement (RSAM): A volcano monitoring and prediction tool, Bull. Volcanol., 53, 533-545,

Fukuzono T, Terashima H, 1985. Experimental study of slope failure in cohesive soils caused by rainfall. In: Int Symp on Erosion, Debris Flow and Disaster Prevention. Tsukuba, Japan

Got J.L., Monteiller V., Guilbert J., Marsan D., Cansi Y., Maillard C., Santoire J.P, 2011. Strain localization and fluid migration from earthquake relocation and seismicity analysis in the western Vosges (France), Geophys. J. Int., 185, 365-384. 
Gutenberg, B., and Richter, C.F., 1956. Earthquake Magnitude, Intensity, Energy and Acceleration (second paper), Bull. Seismol. Soc. Amer., 46, 2, 105-146.

750

751

752

753

754

755

756

757

758

759

760

761

762

763

764

765

766

767

768

769

Hidayat, D., Voight, B., Langston, C., Ratdomopurbo, A., Ebeling, C., 2000. Broadband seismic experiment at Merapi Volcano, Java, Indonesia: very-long-period pulses embedded in multiphase earthquakes. J. Volcanol. Geotherm. Res. 100, 215-231.

Hidayat, D., B. Chouet, B. Voight, P. Dawson and A. Ratdomopurbo, 2002. Source mechanism of very-long-period signals accompanying dome growth activity at Merapi volcano, Indonesia. Geophys. Res. Lett., 29, 23, 2118, doi:10.1029/2002GL015013.

Hidayati, S., Ishihara, K., Iguchi, M. and Ratdomopurbo, A., 2008. Focal mechanism of volcano-tectonic earthquakes at Merapi volcano, Indonesia. Indonesian Journal of Physics, 19(3): 75-82.

Jackson, J.E., 1988. A users guide to principal components, Wiley.

Jolly, A., Neuberg J., Jousset P. and Sherburn S., 2012. New source process for evolving repetitious earthquakes at Ngauraohoe volcano, New Zealand. J. Volcanol. Geotherm. Res., 215-216, 26-36, doi:10.1016/j.jvolgeores.2011.11.010.

Jousset, P., Budi-Santoso A., Jolly A. D., Boichu M., Surono I., Dwiyono S., Sumarti S., Hidayati, S., and Thierry P., 2013. Signs of magmatic ascent in LP and VLP seismicity and link to degassing: an example from the 2010 explosive eruption at Merapi volcano, Indonesia. J. Volcanol. Geotherm. Res. (this issue).

Kilburn, C.R.J., Voight, B., 1998. Slow rock fracture as eruption precursor at Soufriere Hills volcano, Montserrat. Geophys. Res. Lett. 25, 3665-3668.

Kilburn, C.R.J., 2003. Multiscale fracturing as a key to forecasting volcanic eruption. J. Volcanol. Geotherm. Res. 125, 271-289.

Konstantinou, K.I. and Schlindwein, V., 2002. Nature, wavefield properties and source mechanism of volcanic tremor: a review. J. Volcanol. Geotherm. Res., 119, 161-187.

Koulakov, I., Bohm, M., Asch, G., Lühr, B.-G., Manzanares, A., Brotopuspito, K.S., Fauzi, P., Purbawinata, M.A., Puspito, N.T., Ratdomopurbo, A., Kopp, H., Rabbel, W. and Shevkunova, E., 2007. P and S velocity structure of the crust and the upper mantle beneath central Java from local tomography inversion. J. Geophys. Res., 112(B8), B08310, doi: 10.1029/2006JB004712.

Koulakov I. Jakovlev A., and Lühr B.G., 2009. Anisotropic structure beneath central Java from local earthquake tomography, Geochem. Geophys. Geosyst., 10, Q02011, doi:10.1029/2008GC002109.

Lahr, J.C., 1999. HYPOELLIPSE: A computer program for determining local earthquake hypocentral parameters, magnitude and first-motion patterns. U.S. Geological Survey Denver Federal Center, Denver, USA, Open-file report 99-23, paper (112 pp.) and online (http:// greenwood.cr.usgs.gov/pub/open-file-reports/ofr-99-0023). 
Legrand, D., S., Kaneshima, H., Kawakatsu, 2000. Moment tensor analysis of near-field broadband waveforms observed at Aso Volcano, Japan. J. Volcanol. Geotherm. Res. 101(1-2), 155-169, doi: 10.1016/S0377-0273(00)00167-0.

Lesage, P. and Surono, 1995. Seismic precursors of the February 10, 1990 eruption of Kelut volcano, Java. J. Volcanol. Geotherm. Res., 65, 135-146.

Lesage, Ph., Mora, M., Alvarado, G., Pacheco, J. and Metaxian, J.-Ph., 2006. Complex behavior and source model of the volcanic tremor at Arenal volcano, Costa Rica. J. Volcanol. Geotherm. Res., 157, 49-59.

Lühr, B.-G., Maercklin, N., Rabbel, W., Wegler, U., 1998. Active seismic measurements at the Merapi Volcano, Java, Indonesia. Mitteilungen der Deutschen Geophysikalischen Gesellschaft, III, 53-56.

McGarr, A. (1976). Seismic moments and volume changes. Journal of Geophys. Res. 81 (B8): doi: 10.1029/OJGREA0000810000B8001487000001. Issn: 0148-0227.

McNutt, S.R., 1996. Seismic monitoring of volcanoes: A review of the state of the art and recent trens. In: Scarpa, R., and R. Tilling (eds) Monitoring and Mitigation of Volcanic Hazards, Chapter3, Springer-Verlag, Berlin,p. 99-146.

McNutt, S.R., 2000. Volcanic Seismicity, Chapter 63 of Encyclopedia of Volcanoes, Sigurdsson, H., B. Houghton, S.R. McNutt, H. Rymer, and J. Stix (eds.), Academic Press, San Diego, CA, 1015-1033.

Müller, A. and Haak, V., 2004. 3-D modeling of the deep electrical conductivity of Merapi volcano (Central Java): integrating magnetotellurics, induction vectors and the effects of steep topography. J. Volcanol. Geotherm. Res., 138, 205-222.

Newhall, C., Bronto, S., Alloway, B., Banks, N.G., Bahar, I., del Marmol, M.A., Hadisantono, R.D., Holcomb, R.T., MCGeehin, J., Miksic, J.N., Rubin, M., Sayudi, S.D., Sukhyar, R., Andreastuti, S., Tilling, R.I., Torley, R., Trimble, D., Wirakusumah, A.D., 2000. 10000 years of explosive eruptions of Merapi Volcano, Central Java: archaeological and modern implications. J. Volcanol. Geotherm. Res. 100, 9-50.

Ohminato, T., B. Chouet, P. Dawson and S. Kedar, 1998. Waveform inversion of very long period impulsive signals associated with magmatic injection beneath Kilauea Volcano, Hawaii. J. Geophys. Res., 103, B10, 23,839-23862.

Power, J., Lahr, J.C., Page, R.A., Chouet, B., Stephens, C., Harlow, D.H., Murray, T.L. and Davies, J.N., 1994. Seismic evolution of the 1989-1990 eruption sequence of Redoubt volcano, Alaska. J. Volcanol. Geotherm. Res., 62, 69-94.

Qamar, A., St. Lawrence, W., Moore, J.N. and Kendrick, G., 1983. Seismic signals preceding the explosive eruption of Mount St. Helens, Washington, on 18 May 1980. Bull. Seis. Soc. Am., 73(6): 1797-1813.

Ratdomopurbo, A., 1995. Etude Sismologique du Volcan Merapi et Formation du dôme de 1994. PhD Thesis, Université Joseph Fourier-Grenoble I, France. 
Ratdomopurbo, A., and G. Poupinet, 1995. Monitoring a temporal change of seismic velocity in a volcano: application to the 1992 eruption of Mt. Merapi (Indonesia), Geophys. Res. Lett., 22 (7), 775-778,

Ratdomopurbo, A. Poupinet, G., 2000. An overview of the seismicity of Merapi volcano, (Java, Indonesia), 1983-1995. J. Volcanol. Geotherm. Res. 100, 193-214.

Rust, A.C., Balmforth, N.J. and Mandre, S., 2008. The feasibility of generating low-frequency volcano seismicity by flow through a deformable channel. In: S.J. Lane and J.S. Gilbert (Editors), Fluid motions in volcanic conduits: a source of seismic and acoustic signals. Geological Society, Special Publications, London, pp. 45-56.

Saccorotti, G., Bianco, F., Castellano, M. and Del Pezzo, E., 2001. The July-August 2000 seismic swarms at Campi Flegrei volcanic complex, Italy. Geophys. Res. Lett., 28(13), 2525-2528.

Sens-Schönfelder, C., 2008. Synchronizing seismic networks with ambient noise. Geophys. J. Int., 174, 966-970.

Smith, R. Kilburn, C. R. J., Sammonds, P. R., 2007. Rock fracture as a precursor to lava dome eruptions at Mount St Helens from June 1980 to October 1986. Bull Volcanol. 69, 681-693, DOI 10.1007/s00445-006-0102-5

Stehly, L., Campillo, M. and Shapiro, N.M., 2007. Traveltime measurements from noise correlation: stability and detection of instrumental time-shifts. Geophys. J. Int., 171: 223-230, doi: 10.1111/j.1365-246X.2007.03492.x.

Stephens, C., Chouet, B.A., Page, R.A., Lahr, J.C. and Power, J.A., 1994. Seismological aspects of the 1989-1990 eruptions at Redoubt volcano, Alaska: the SSAM perspective. J. Volcanol. Geotherm. Res., 62: 153-182.

Sri-Sayudi D., Muzani M., Nurnusanto I., 2007. Sebaran awanpanas dan daya tampung sungai-sungai yang terisi material erupti 2006. Edisi Khusus Merapi 2006: Laporan dan Kajian Vulkanisme Erupsi. Pusat Vulkanologi dan Mitigasi Bencana Geologi.

Suharna, Budi-Santoso A., Dwiyono S., Jilal M., 2007. Statistik dan analisis seismisitas Merapi 2006. Edisi Khusus Merapi 2006: Laporan dan Kajian Vulkanisme Erupsi. Pusat Vulkanologi dan Mitigasi Bencana Geologi.

Surono , Jousset P., Pallister J., Boichu M., Buongiorno M. F., Budi-Santoso A., Costa F., Andreastuti S., Prata F., Schneider D. , Clarisse L., Humaida H., Sumarti S., Bignami C., Griswold J., Carn S. and Oppenheimer C., 2012. The 2010 explosive eruption of Java's Merapi volcano - a '100-year' event. J. Volcanol. Geotherm. Res. 241-242, 121 135

Thomson, R., 1985. A note on restricted Maximum Likelihood Estimation with an alternative outliers model. J.R. Statist. Soc. B., 47, 53-55.

Tokarev, P.I., 1971. Forecasting volcanic eruptions from seismic data. Bull. Volcanol., 35, 243-250. 
91

2

Tokarev, P.I., 1985. The prediction of large explosions of andesitic volcanoes. J Geodynamics, 3, 219-244.

Traversa, P., O. Lengliné, O. Macedo, J. P. Metaxian, J. R. Grasso, A. Inza, and E. Taipe, 2011. Short term forecasting of explosions at Ubinas volcano, Perú, J. Geophys. Res., 116, B11301, doi:10.1029/2010JB008180.

Voight B, 1988. A method for prediction of volcanic eruptions. Nature 332, 125-130

Voight, B., Constantine, E. K., Sismowidjoyo, S., Torley, R., 2000. Historical eruptions of Merapi Volcano, Central Java, Indonesia, 1768-1998. J. Volcanol. Geotherm. Res. 100, 69-138.

Wagner D., I. Koulakov, W. Rabbel, B-G. Lühr, A. Wittwer, H. Kopp, M. Bohm, G. Asch and the MERAMEX scientists, 2007. Joint inversion of active and passive seismic data in Central Java, Geophys. J. Int., 170, 923-932.

Waite, G. P., B. A. Chouet, and P. B. Dawson, 2008. Eruption dynamics at Mount St. Helens imaged from broadband seismic waveforms: Interaction of the shallow magmatic and hydrothermal systems, J. Geophys. Res., 113, B02305, doi:10.1029/2007JB005259

Wassermann, J., and M. Ohrnberger, 2001. Automatic hypocenter determination of volcano induced seismic transients based on field coherence -an application to the 1998 eruption of Mt. Merapi, Indonesia, J. Volcanol. Geotherm. Res., 110, 57-77.

Wegler, U., Lühr, B.-G. and Ratdomopurbo, A., 1999. A repeatable seismic source for tomography at volcanoes. Annali di Geofisica, 42(3), 565-571.

Wegler, U., and B. Lühr, 2001. Scattering behaviour at Merapi volcano (Java) revealed from an active seismic experiment. Geophys. J. Intern., 145, 3, 579-592, 10.1046/j.1365246x.2001.01390.x.

Wegler, U., B.-G. Lühr, R. Snieder, and A. Ratdomopurbo, 2006. Increase of shear wave velocity before the 1998 eruption of Merapi volcano (Indonesia), Geophys. Res. Lett., 33, L09303, doi:10.1029/2006GL025928.

Yokoyama, I., 1988. Seismic energy release from volcanoes. Bull. Volcanol., 50, 1-13.

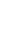


894

895

896

897

898

899

900

901

902

903

904

905

906

907

908

909

910

911

912

913

914

915

916

917

918

919

920

921

922

923

924

925

926

927

928

929

930

931

932

Fig. 1. Monitoring network of Merapi and location of short-period and broadband stations, EDM reflectors and observation posts. Distance from Kaliurang observation post to reflectors RK (dotted line) was measured by EDM. Another seismic station (CRM) located at $40 \mathrm{~km}$ south from Merapi is out of range of the map.

Fig. 2. Operation intervals of seismic stations in 2009 and 2010. Black vertical line indicates end of year 2009. Dotted vertical lines show first eruption onset (October $26^{\text {th }}$ at 10:02) and the largest eruption (November $4^{\text {th }}$ at 17:01 UTC or November $5^{\text {th }}$ at 00:01 local time). Most of the stations were destroyed by the later eruptions.

Fig. 3. Clock synchronization by seismic noise cross-correlation. Two VT events recorded by stations LBH (top) and PUS (middle) when they were synchronized (a) and while GPS clock of LBH was out of order (b). Cross-correlation functions of noise (CCF, bottom panels) between the two stations when clocks were either synchronized (a) or not (b). Time lag between the two CCF is used to correct the clock drift.

Fig. 4. Different types of event observed on Merapi. For each sample, waveforms recorded at two stations and spectrogram are displayed. a) volcanotectonic A; b) volcanotectonic B; c) multiphase; d) low-frequency.

Fig. 5. An episode of tremor that occurred on October $1^{\text {st }}$, 2010 05:42. Seismogram recorded at station PUS, spectrogram, and spectrum calculated on short window around 5000 seconds.

Fig. 6. Seismogram of station PUS on November $4^{\text {th }}$ until station destruction $(\sim 21: 30)$. Dotted vertical line indicates onset of largest eruption at 17:01 UTC. Although record was saturated, the eruption could be detected in low pass filtered $(\mathrm{f}<0.1 \mathrm{~Hz})$ seismogram (bottom panel).

Fig. 7. Seismogram of first swarm of October $31^{\text {st }}$, 2009. It lasted about 3 hours. Another larger VT event occurred about 3 hours afterward (right edge of plot).

Fig. 8. Daily numbers of events for period September-December 2010. Dash-dot vertical lines indicate date of alert level rising. Bottom panel shows daily RSAM obtained at the observatory. The RSAM value on November $5^{\text {th }}$ is about 5 times that of October $26^{\text {th }}$.

Fig. 9. Comparison of cumulative energy release of VT and MP earthquakes during one year prior to several eruptions from 1992 to 2010 .

Fig. 10. Hypocenters of VT earthquakes. a) Map of epicenters, b) NS cross section, c) EW cross section. Hypocenters are indicated by crosses, with their $67 \%$ confidence interval (pink ellipses). d) Histogram of the hypocenter depths (black solid bar) and probability density function of source depths (black hollow bar), calculated using Monte Carlo method. e) Histogram of uncertainties on depth. f) Depths as a function of differences of P-wave arrival times between stations DEL and PUS.

Fig. 11. Depth of events plotted as a function of time on periods of a) October 2009-October 2010 and b) September-October 2010. Daily numbers of VTA and VTB events are shown by red and blue lines, respectively.

Fig. 12. a) SSAM and its cumulative value for the range [1-3] Hz. b) RSAM and its cumulative value calculated with signals whose dominant frequency is in the interval [1-3] 
Hz. c) Same as b), after removing the tectonic events. A marked increase of LF activity

934 appears more clearly in the last few days before the eruption.

935 Fig. 13. RSAM calculated from station PUS (blue area) and its cumulative value (black line) 936 during 3 months prior eruption. Cumulative RSAM for signals with dominant frequency in 937 the ranges $0.01-0.1 \mathrm{~Hz}$ (yellow line), $1-3 \mathrm{~Hz}$ (brown line), $3-5 \mathrm{~Hz}$ (green line), $5-10 \mathrm{~Hz}$ 938 (magenta line), and 1-15 Hz (red line). Brown dashed vertical lines and arrows indicate main 939 explosions.

940 Fig. 14. Cumulative RSAM (black line) before eruptions. Theoretical curves calculated with 941 FFM with fitting windows from September $13^{\text {th }}$ to October $5^{\text {th }}$ (red line) and from October $7^{\text {th }}$ 942 to $26^{\text {th }}$ (blue line).

943 Fig. 15. Difference between predicted time $t_{f}$ and time of eruption onset $t_{\text {erupt }}$ as a function of 944 ending time of the fitting window $t_{\text {end }}$, and calculated with $t_{\text {start }}=$ October $7^{\text {th }}$. Observations are 945 a) unfiltered RSAM, b) RSAM calculated for signals with dominant frequency in the range $9460.01-1 \mathrm{~Hz}, \mathrm{c}$ ) same for $3-5 \mathrm{~Hz}$, d) $5-10 \mathrm{~Hz}$, e) $1-15 \mathrm{~Hz}$, and f) variation of the slope distance 947 measured by EDM.

948 Fig. 16. Variation of the slope distance between Kaliurang observatory and the southern part 949 of the summit (circle) and theoretical curves (black line) obtained with different ending times 950 of the fitting windows. Starting time is October $7^{\text {th }}$.

951

952

953

954

955

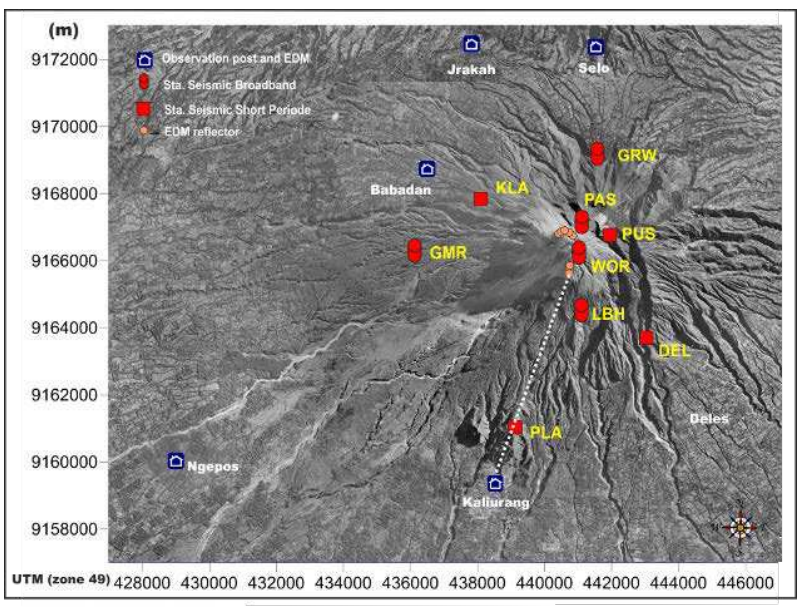

Figure 1. 


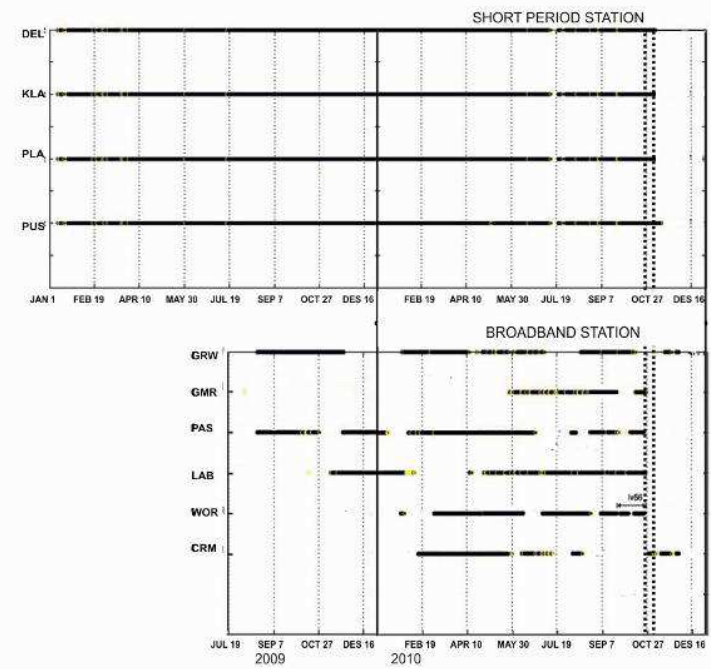

957 Figure 2.

958
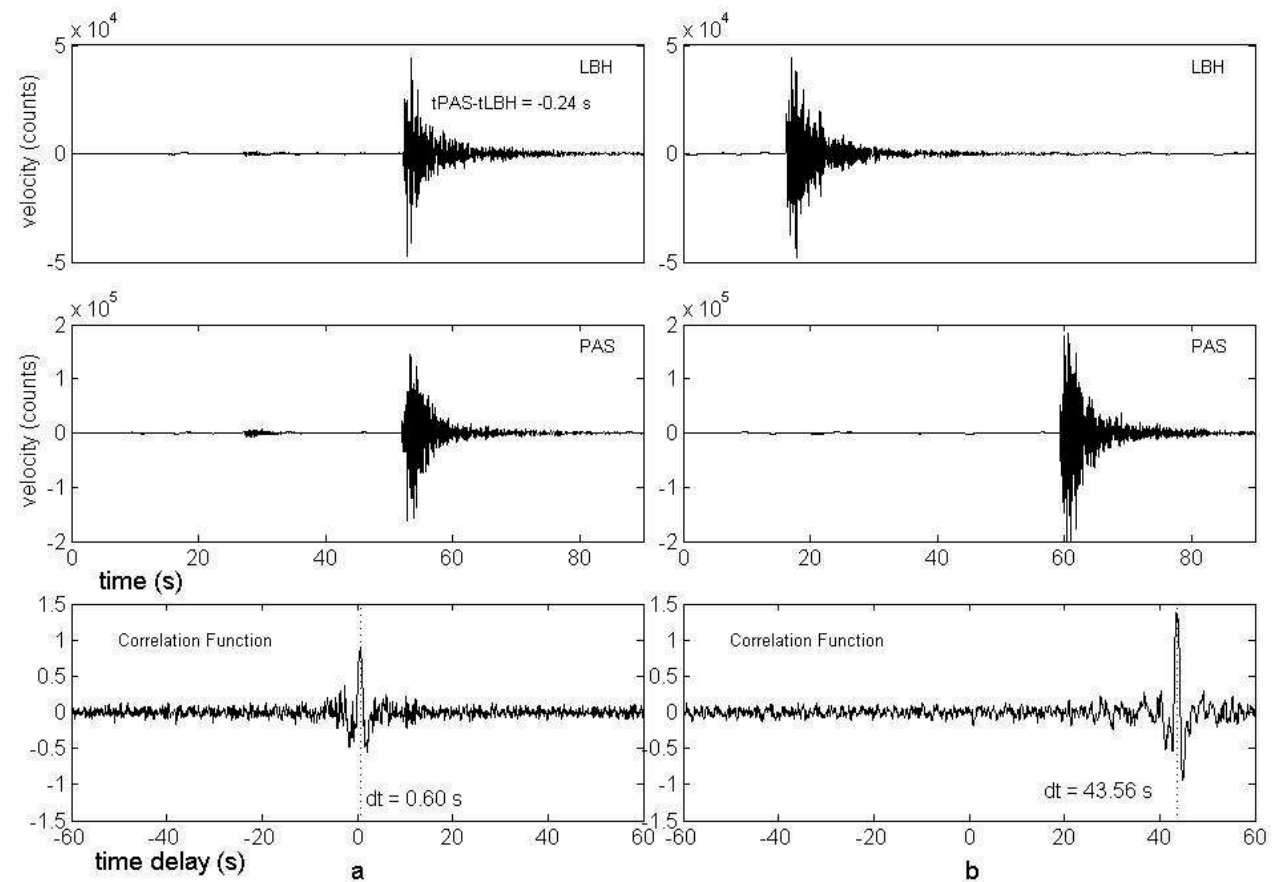

959

$960 \quad$ Figure 3. 


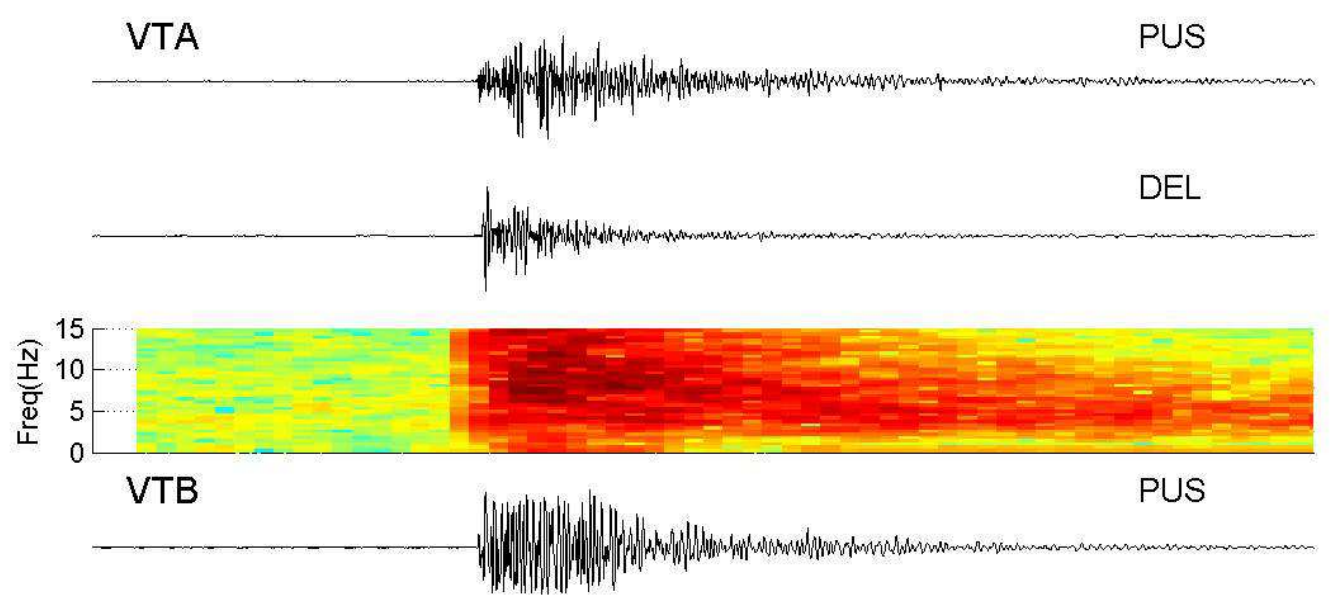

\section{DEL}

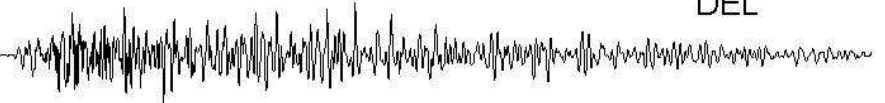

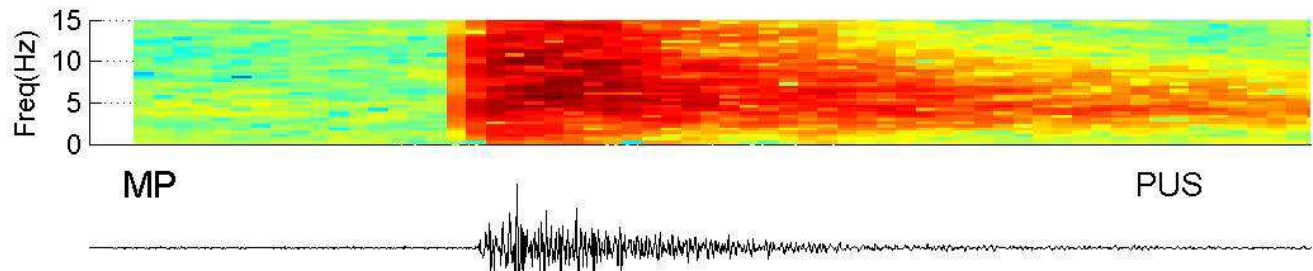

DEL

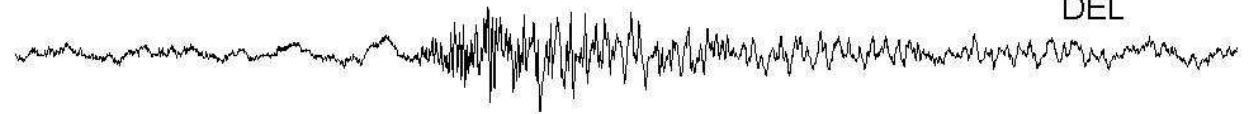

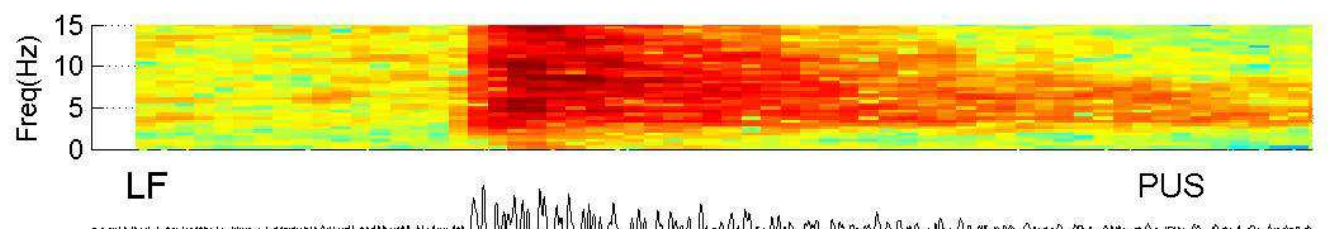

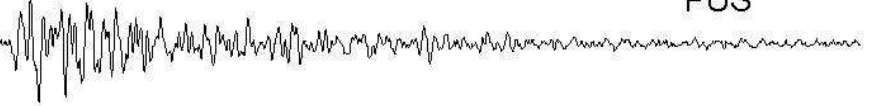
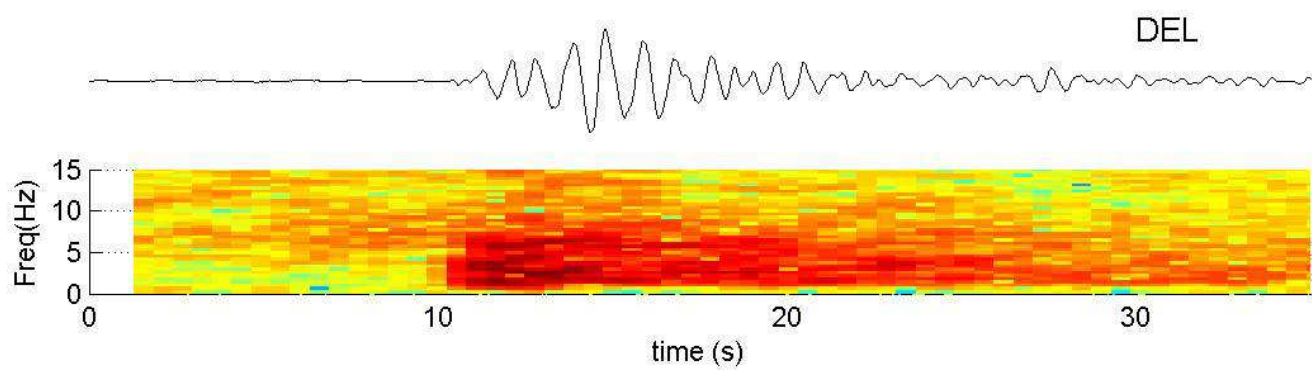

Figure 4. 

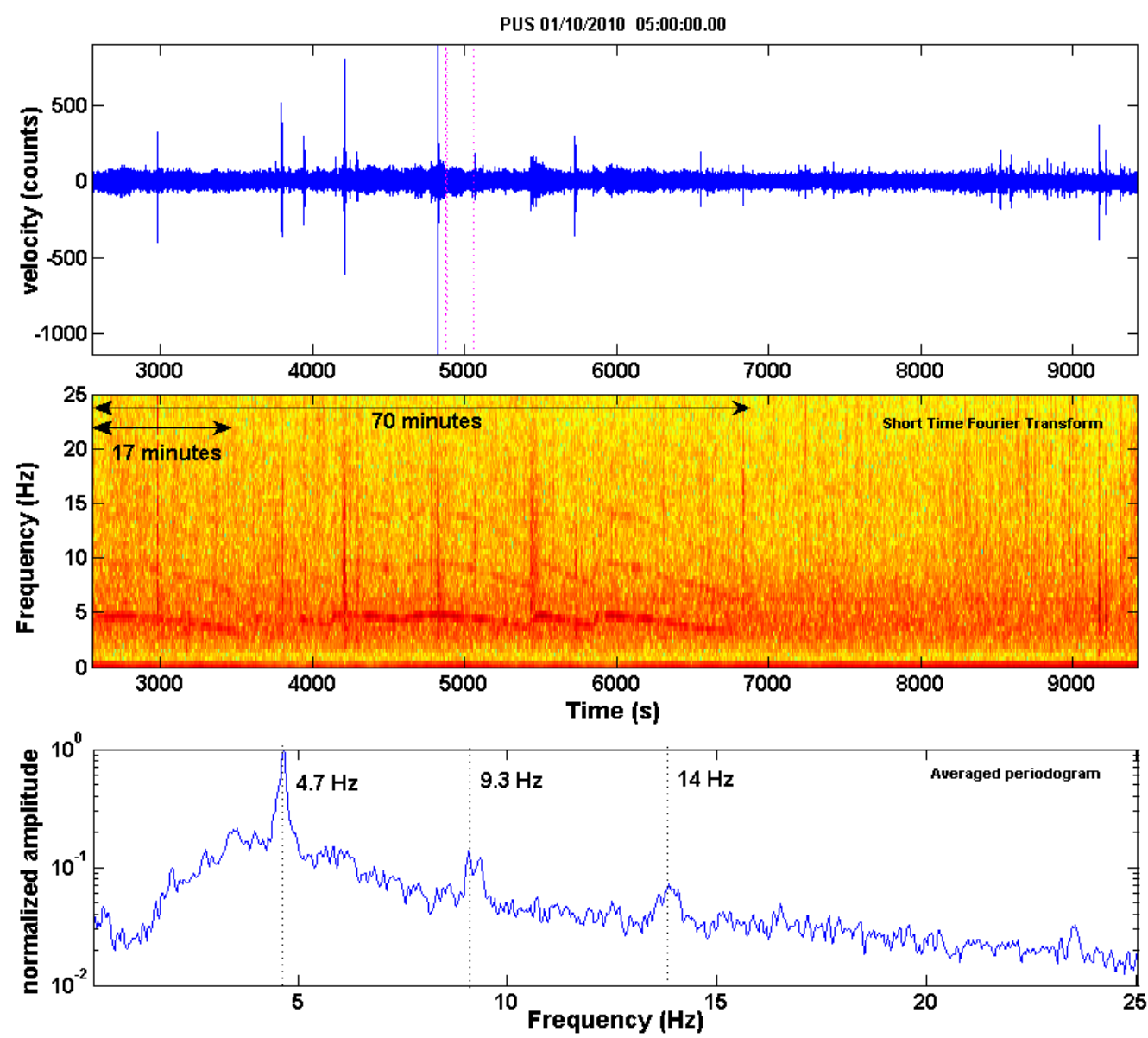

966 Figure 5.

967

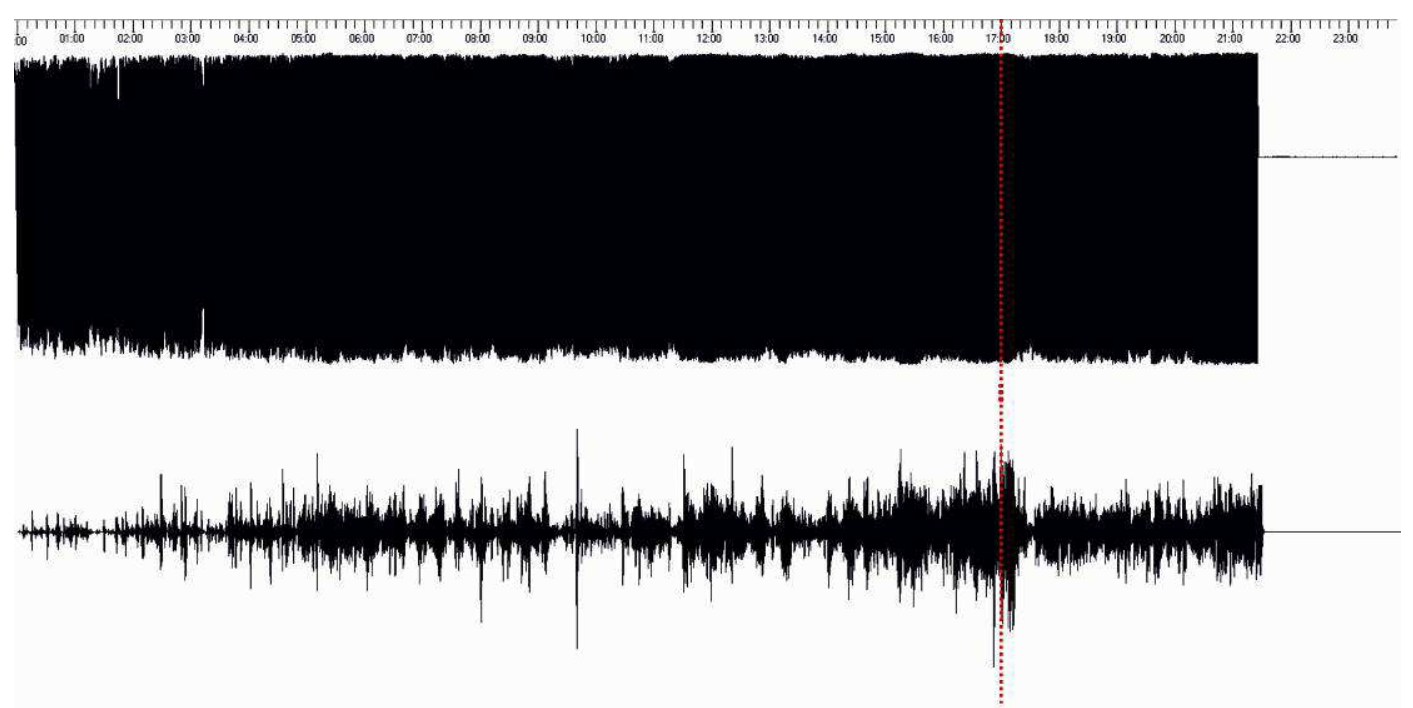

Figure 6. 


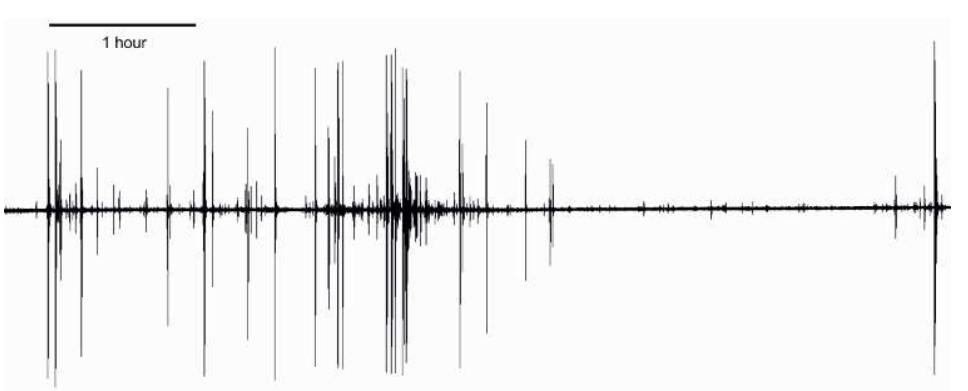

970

Sta. PUS October 31th, 2009 03:00

971 Figure 7.

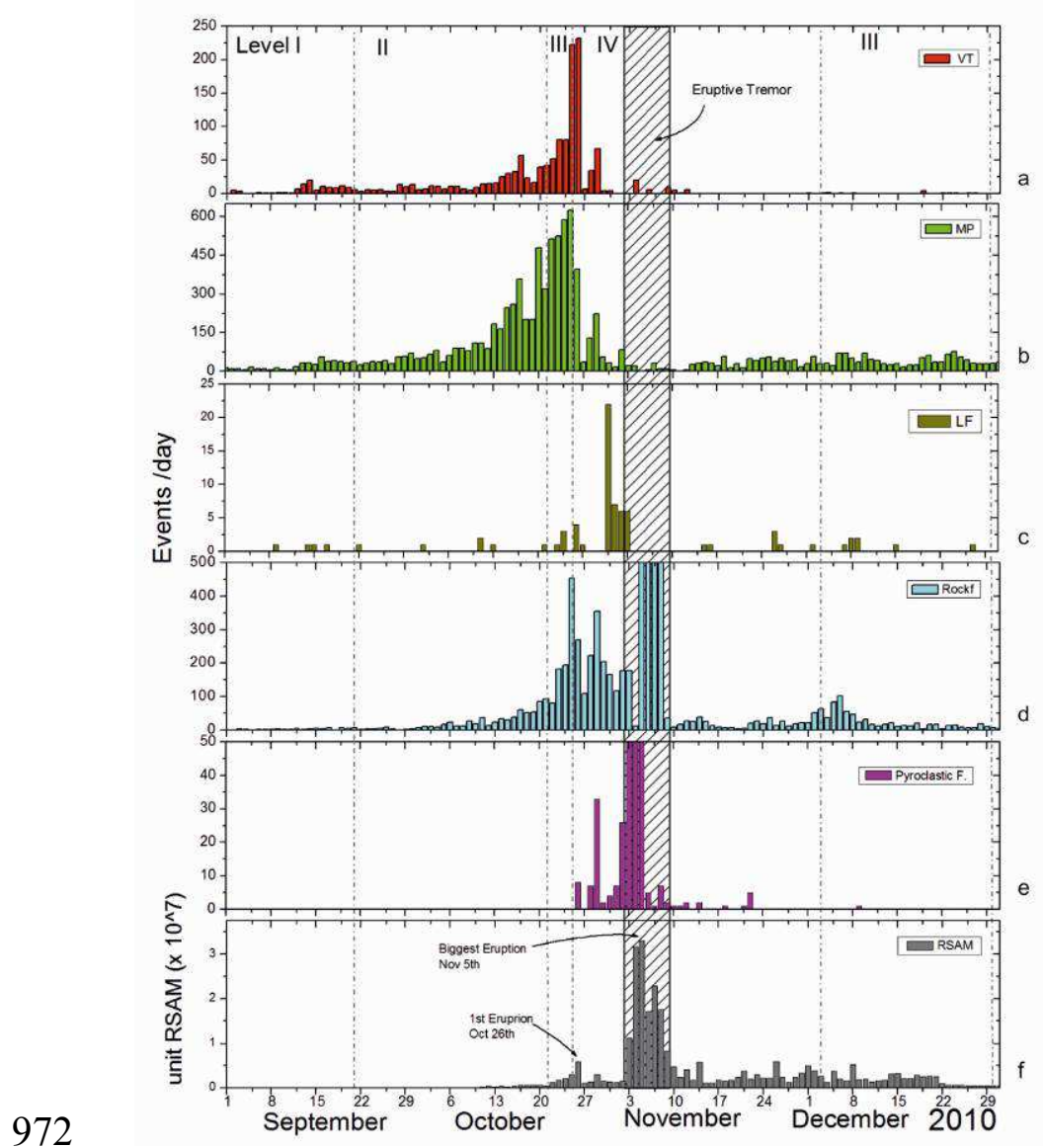

$973 \quad$ Figure 8 


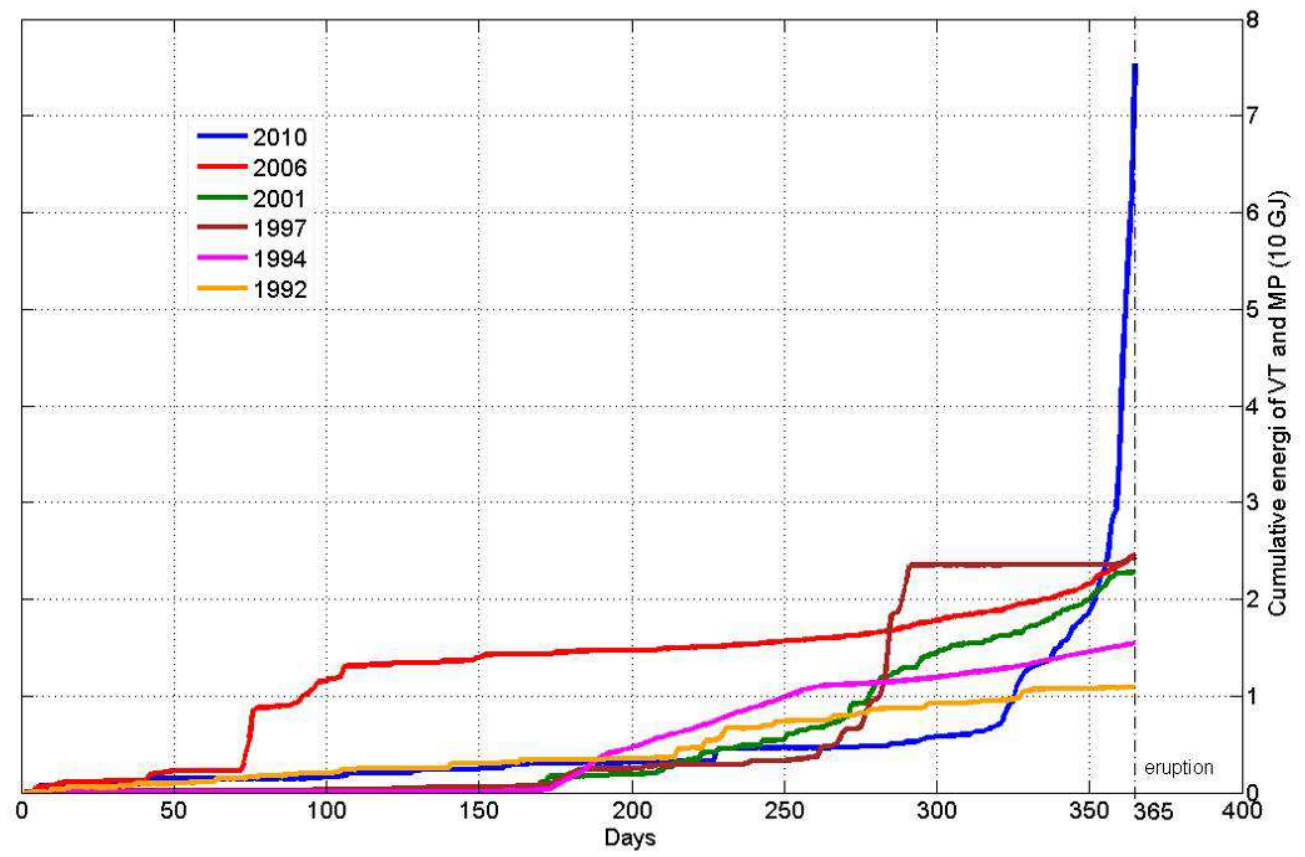

974

975 Figure 9. 

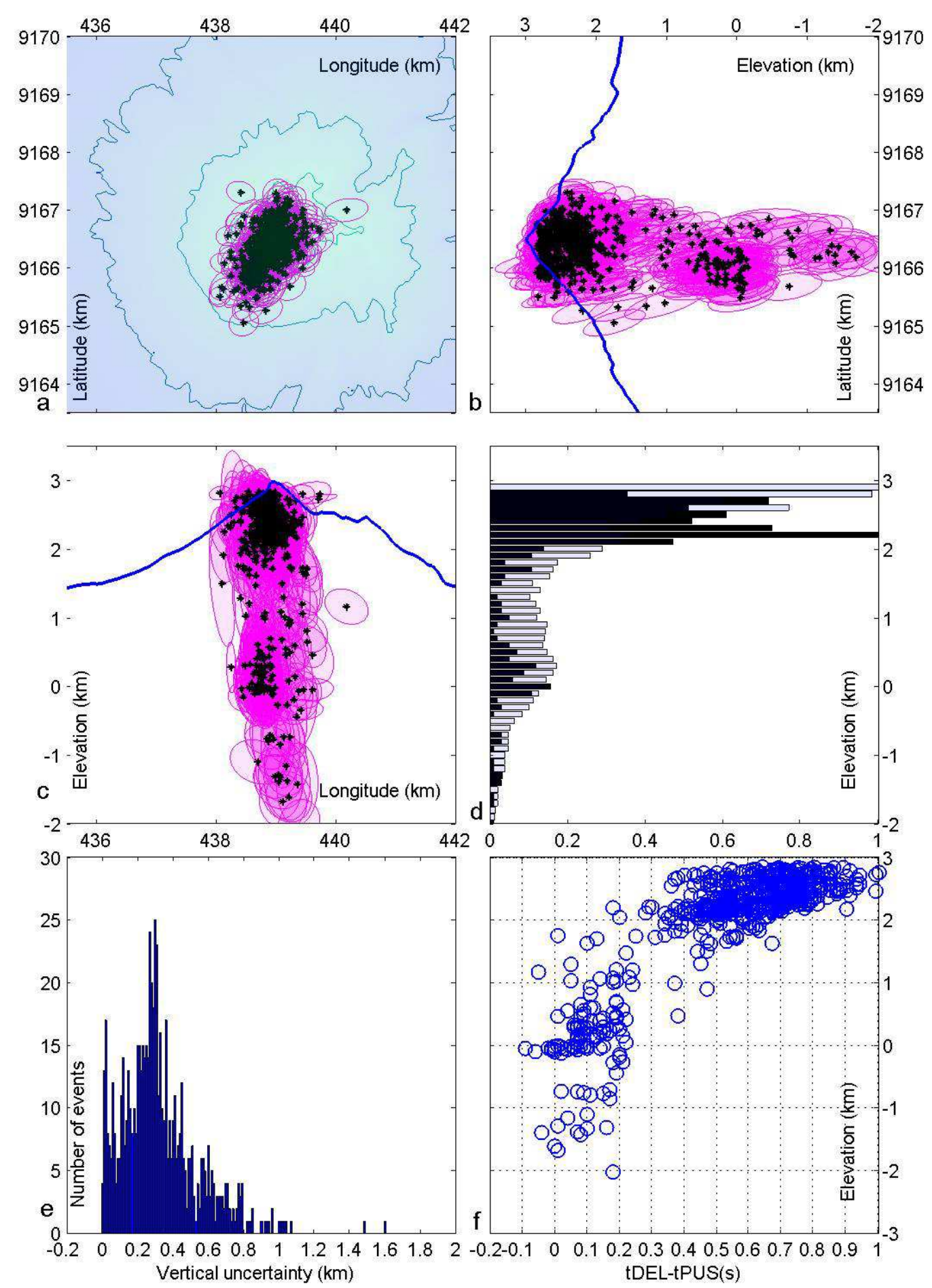

977 Figure 10. 

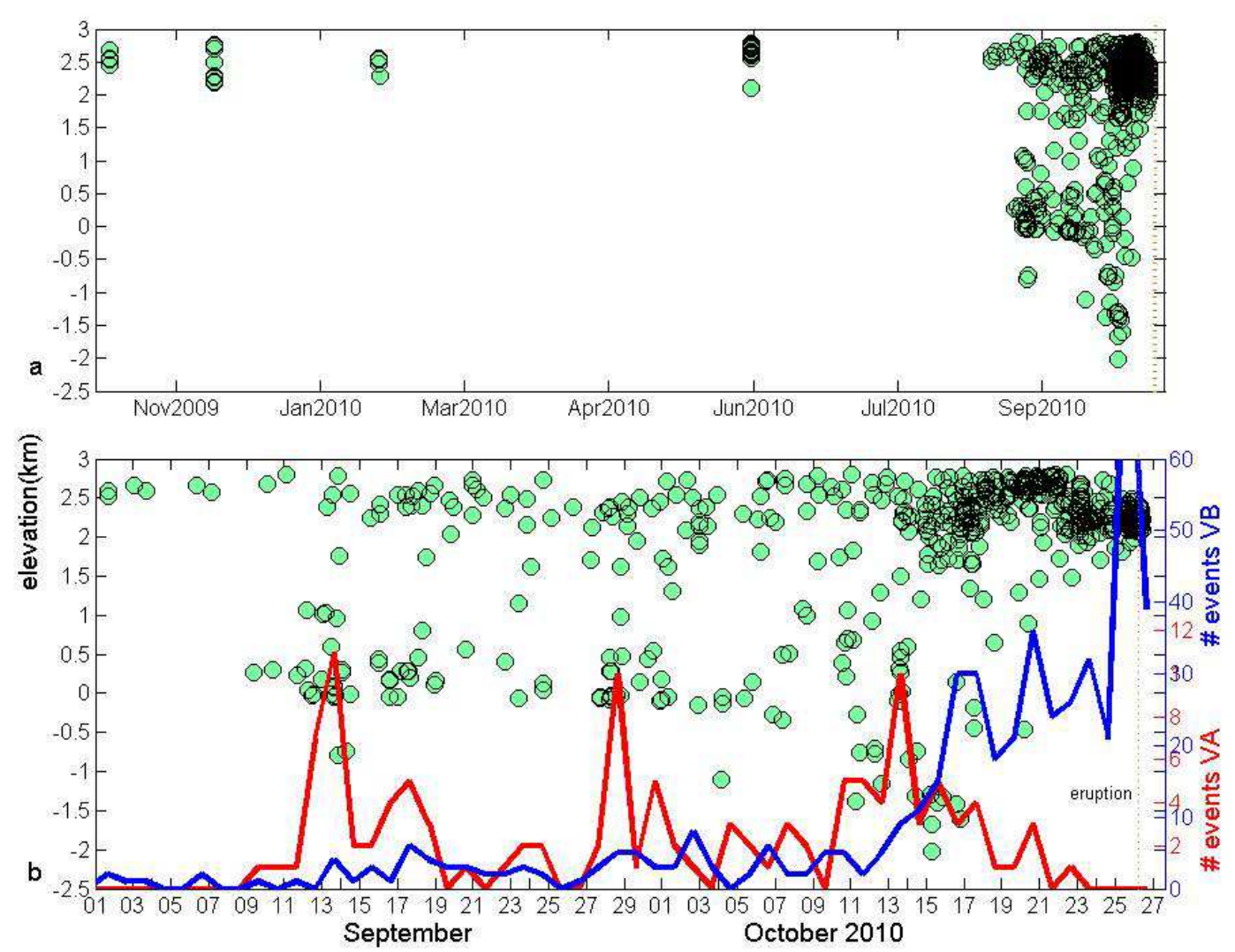

978

979 Figure 11 


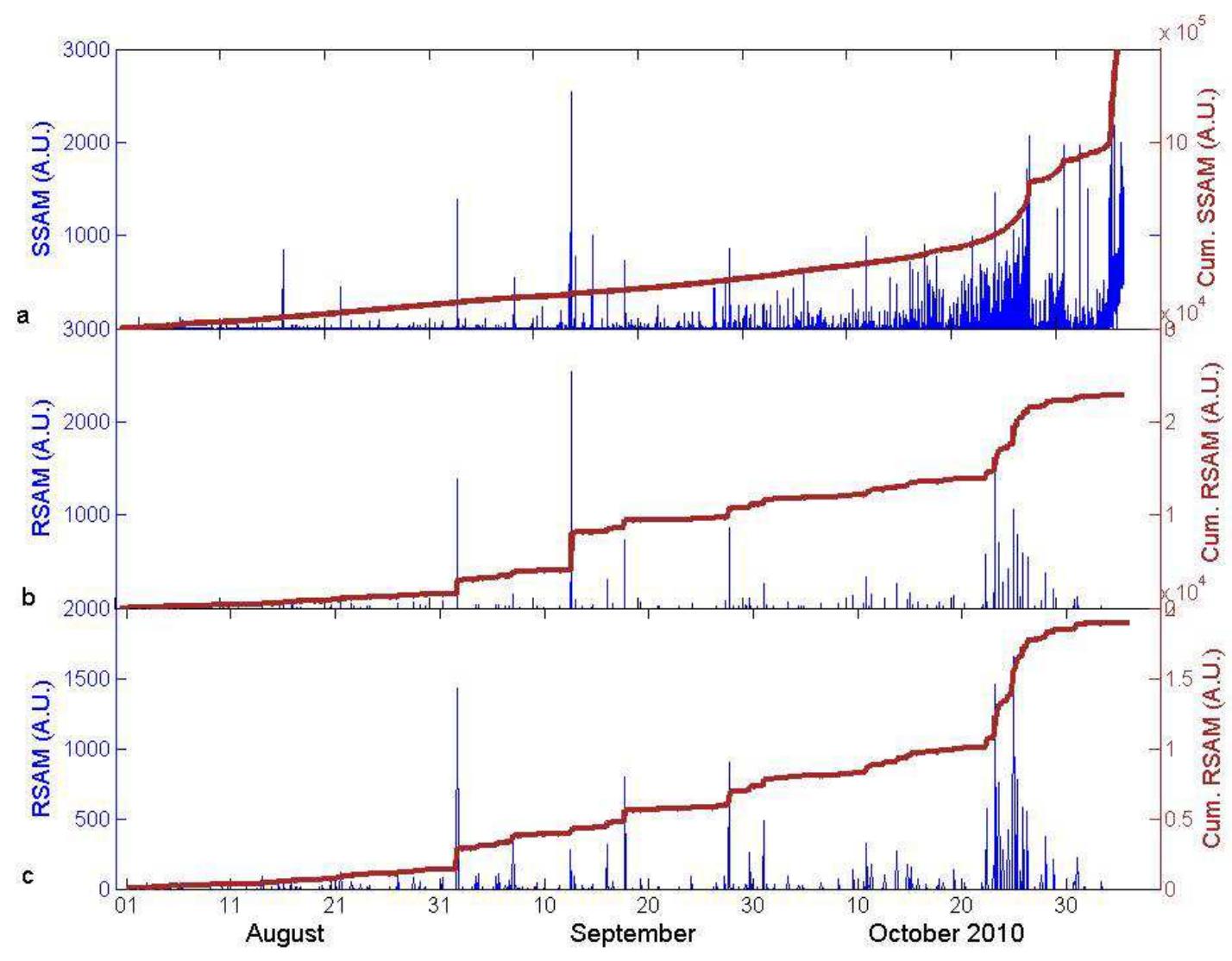

980

981 Figure 12 


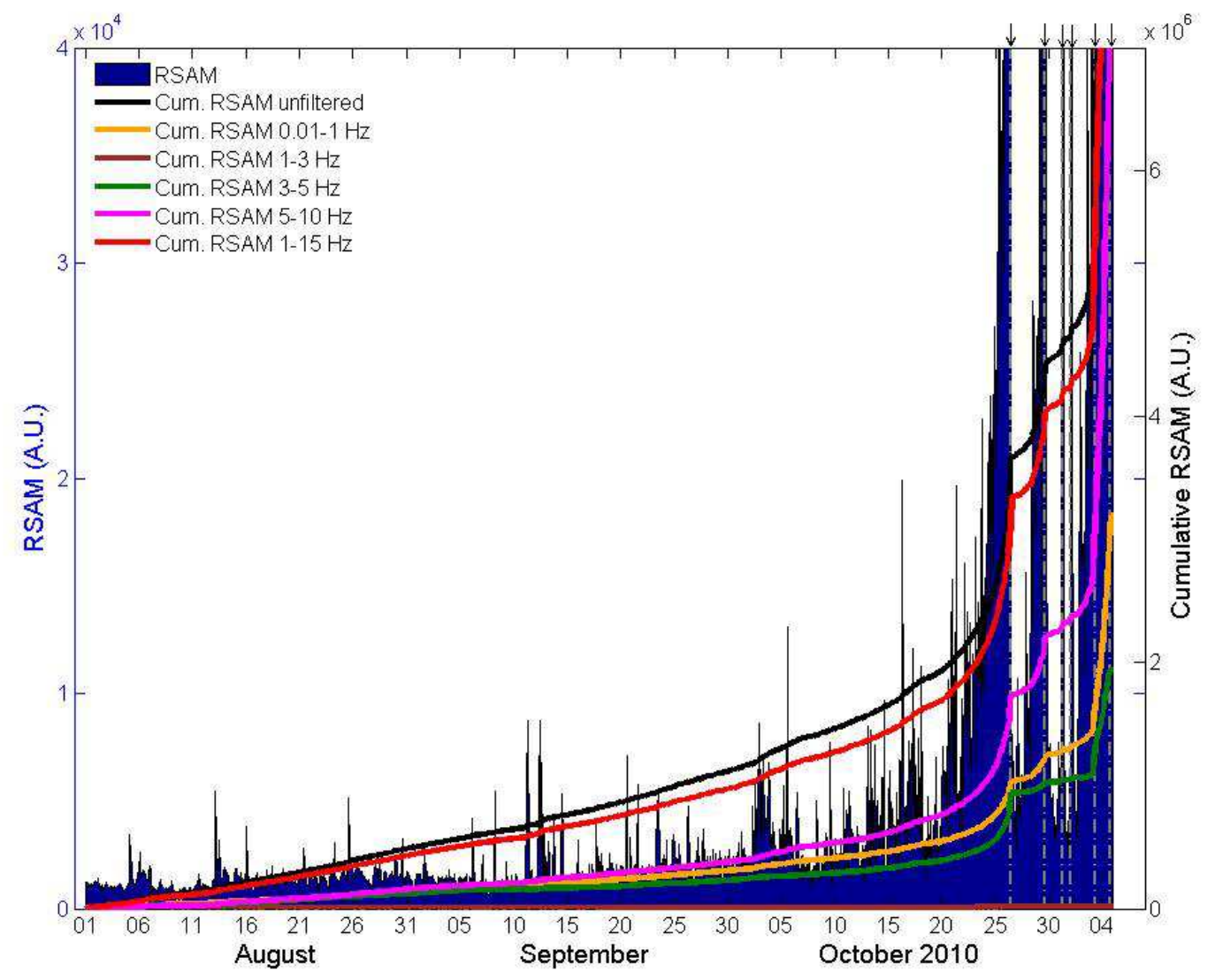

982

983 Figure 13 


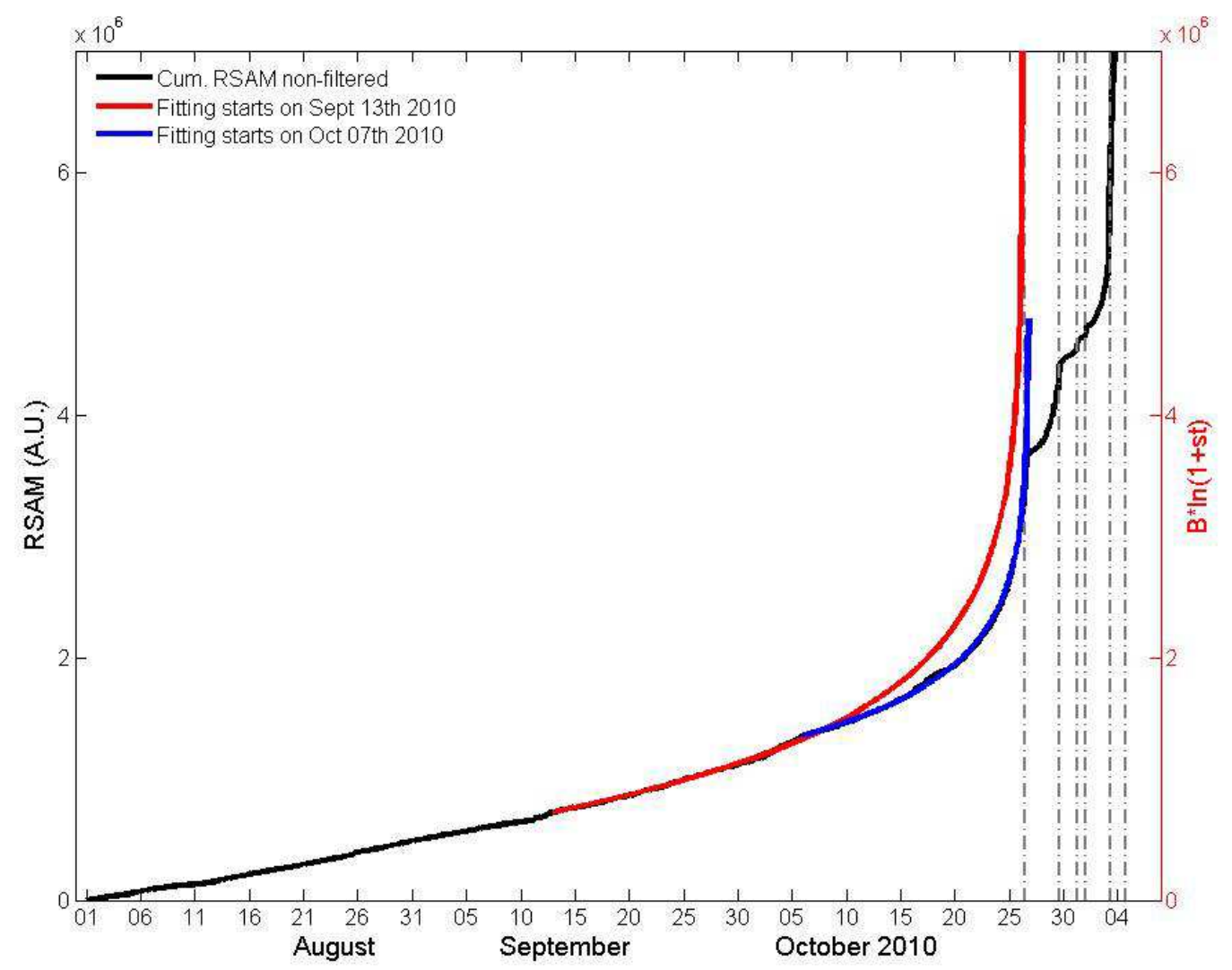

984

985 Figure 14

986 

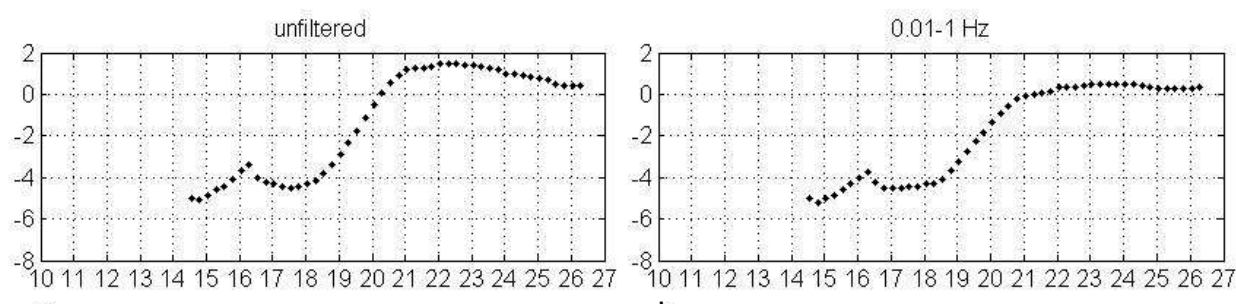

a

$3-5 \mathrm{~Hz}$

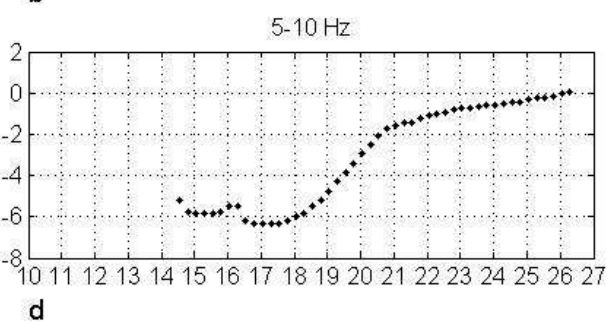

101112131415161718192021222324252627

c

$1-15 \mathrm{~Hz}$

EDM

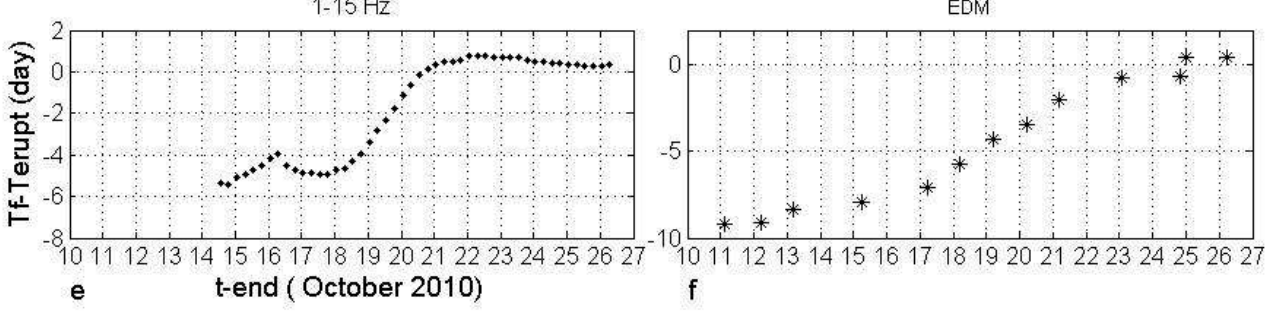

987

988 Figure 15 


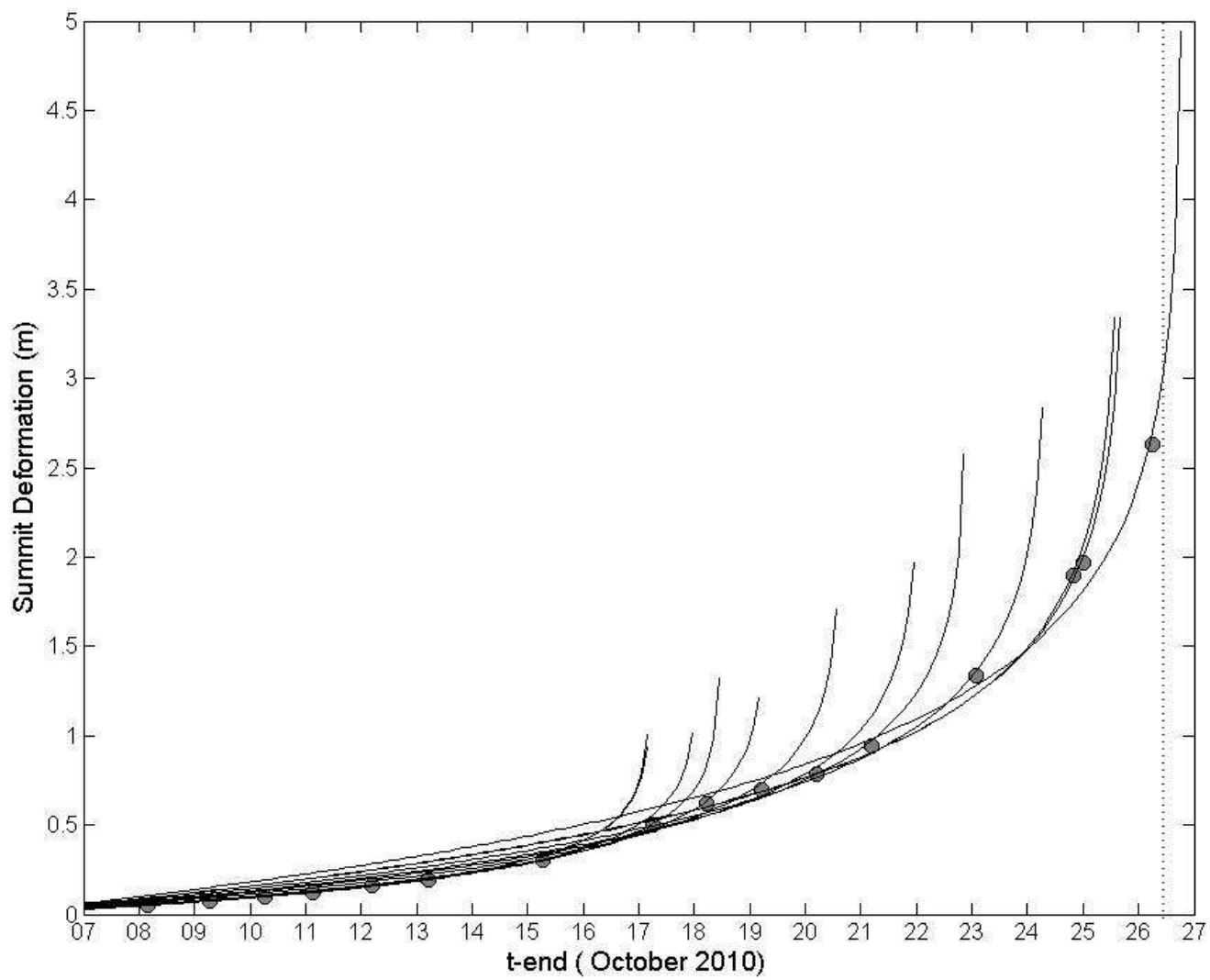

989

$990 \quad$ Figure 16 